\title{
A systematic literature review of the disease burden in patients with recessive dystrophic epidermolysis bullosa
}

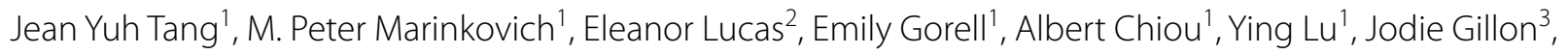
Dipen Patel $^{2}$ and Dan Rudin ${ }^{3^{*}}$ (D)

\begin{abstract}
Background/objective: Recessive dystrophic epidermolysis bullosa (RDEB) is a genetic collagen disorder characterized by skin fragility leading to blistering, wounds, and scarring. There are currently no approved curative therapies. The objective of this manuscript is to provide a comprehensive literature review of the disease burden caused by RDEB.
\end{abstract}

Methods: A systematic literature review was conducted in MEDLINE and Embase in accordance with PRISMA guidelines. Observational and interventional studies on the economic, clinical, or humanistic burden of RDEB were included.

Results: Sixty-five studies were included in the review. Patients had considerable wound burden, with 60\% reporting wounds covering more than $30 \%$ of their body. Increases in pain and itch were seen with larger wound size. Chronic wounds were larger and more painful than recurrent wounds. Commonly reported symptoms and complications included lesions and blistering, anemia, nail dystrophy and loss, milia, infections, musculoskeletal contractures, strictures or stenoses, constipation, malnutrition/nutritional problems, pseudosyndactyly, ocular manifestations, and dental caries. Many patients underwent esophageal dilation (29-74\%; median dilations, 2-6) and gastrostomy tube placement (8-58\%). In the severely affected population, risk of squamous cell carcinoma (SCC) was $76 \%$ and mortality from SCC reached $84 \%$ by age 40 . Patients with RDEB experienced worsened quality of life (QOL), decreased functioning and social activities, and increased pain and itch when compared to other EB subtypes, other skin diseases, and the general population. Families of patients reported experiencing high rates of burden including financial burden (50-54\%) and negative impact on private life (79\%). Direct medical costs were high, though reported in few studies; annual payer-borne total medical costs in Ireland were $\$ 84,534$ and annual patient-borne medical costs in Korea were $\$ 7392$. Estimated annual US costs for wound dressings ranged from $\$ 4000$ to $\$ 245,000$. Patients spent considerable time changing dressings: often daily (13-54\% of patients) with up to three hours per change (15-40\%).

Conclusion: Patients with RDEB and their families/caregivers experience significant economic, humanistic, and clinical burden. Further research is needed to better understand the costs of disease, how the burden of disease changes

\footnotetext{
*Correspondence: sfriedhoff@abeonatherapeutics.com;

drudin@abeonatherapeutics.com

${ }^{3}$ Abeona Therapeutics Inc, 1330 Avenue of the Americas, New York, NY

10019, USA

Full list of author information is available at the end of the article
}

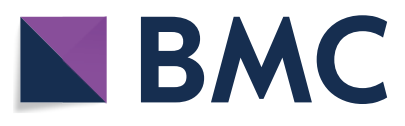

(c) The Author(s) 2021. Open Access This article is licensed under a Creative Commons Attribution 4.0 International License, which permits use, sharing, adaptation, distribution and reproduction in any medium or format, as long as you give appropriate credit to the original author(s) and the source, provide a link to the Creative Commons licence, and indicate if changes were made. The images or other third party material in this article are included in the article's Creative Commons licence, unless indicated otherwise in a credit line to the material. If material is not included in the article's Creative Commons licence and your intended use is not permitted by statutory regulation or exceeds the permitted use, you will need to obtain permission directly from the copyright holder. To view a copy of this licence, visit http://creativecommons.org/licenses/by/4.0/. The Creative Commons Public Domain Dedication waiver (http://creativeco mmons.org/publicdomain/zero/1.0/) applies to the data made available in this article, unless otherwise stated in a credit line to the data. 
over the patient lifetime and to better characterize QOL impact, and how RDEB compares with other chronic, debilitating disorders.

Keywords: Recessive dystrophic epidermolysis bullosa, Burden of disease, Systematic literature review

\section{Introduction}

Recessive dystrophic epidermolysis bullosa (RDEB) is a rare, severe form of dystrophic epidermolysis bullosa (DEB), a genetic collagen disorder characterized by skin fragility and scarring of the skin from birth onwards. Patients with this disorder inherit mutations in both alleles of COL7A1, the gene which produces type VII collagen (C7). This leads to absences or irregularities in $\mathrm{C} 7$ and alterations in the character and number of anchoring fibrils, which secure the skin's dermal layer to the epidermal layer [1]. Due to these mutations, patients with RDEB can experience blistering at the dermal layer with only minimal trauma.

An analysis of the United States (US) National Epidermolysis Bullosa (EB) Registry, funded and operated from 1986 to 2002, reported RDEB incidence of 3.05 cases per one million live births and prevalence of 1.35 cases per one million live births [2]. However, a more recent genotypic modeling of publicly available whole-exome and whole-genome sequencing estimated an incidence of 95 cases per one million births. This suggests that the National EB Registry estimates may be significantly understated, potentially due to underestimation of less severe cases of RDEB, likely mis-diagnosed as EB Simplex or de novo variants of Dominant Dystrophic EB (DDEB) [3]. This underestimation may also result in overestimation of systemic and severe manifestations.

RDEB is typically diagnosed clinically and often confirmed through assessment of immunofluorescence or electron microscopy on skin biopsy or by genetic testing [4]. RDEB is divided into several subtypes: severe (characterized by absent or markedly reduced $\mathrm{C7}$ ), intermediate (characterized by reduced $\mathrm{C7}$ ), and other, rarer, subtypes including inversa, localized, or pruriginosa [5].

Cutaneous signs of the disease include blistering and wounding in response to mechanical traumas, milia, atrophic scarring, dystrophic or absent nails, and alopecia. Pruritus is also a frequent complaint. Chronic wounding and fibrosis is generally believed to favor the frequent development of aggressive squamous cell carcinoma (SCC), which represents a leading cause of premature death in patients with severe and intermediate RDEB $[4,6] .^{1}$ Extracutaneous manifestations include anemia,

\footnotetext{
${ }^{1}$ All costs were converted to USD based on November 5, 2020 exchange rate.
}

growth retardation, dental caries, pseudosyndactyly, esophageal strictures, malnutrition, and ocular involvement [4].

Currently, there are no approved disease-modifying therapies for RDEB. Treatment of the disease is limited to management of symptoms and secondary complications, such as wound care, prevention of trauma, treatment of infections, pain and itch management, strategic wrapping of the hands and feet to prevent pseudosyndactyly, and early detection and treatment of SCC $[1,7,8]$. Gastrointestinal manifestations of the disease are managed through proactive nutritional support including gastrostomy feeding, esophageal dilation, and treatment of anemia $[1,8]$. Other areas of disease management include physical therapy and rehabilitation, psychosocial and group support, and extra schooling accommodations [1, $7,9]$.

Due to the high unmet need for corrective treatments, the Food and Drug Administration released guidance for industry on the development of drugs for treatment of cutaneous manifestations of EB in June 2019, identifying drug development and trial design, population, and evaluation as issues specific to patients [10]. An increasing number of clinical trials are being conducted in cellbased therapies, gene and molecular therapies, protein replacement therapies, exon skipping molecular therapies, and drug-mediated premature termination codon read-throughs targeted to manage and treat RDEB [11]. Gene therapies, which involve the transfer of functional COL7A1 gene to the patient with RDEB, appear to be promising potential treatments, likely available in the near future [12-14].

Many narrative and expert reviews provide a commentary on RDEB; however, no reviews use a systematic method to evaluate the literature regarding burden of disease in this patient population. This paper aims to systematically review and synthesize the data regarding the clinical, humanistic, and economic burden of RDEB. Abeona Therapeutics, a company developing EB-101, investigational autologous COL7A1 gene-corrected keratinocytes sheets for the treatment of large and chronic RDEB wounds, initiated this review to fully characterize disease burden, and its employees (J.G and D.R.) co-authored the paper. Pharmerit conducted the literature review and generated the first draft. 


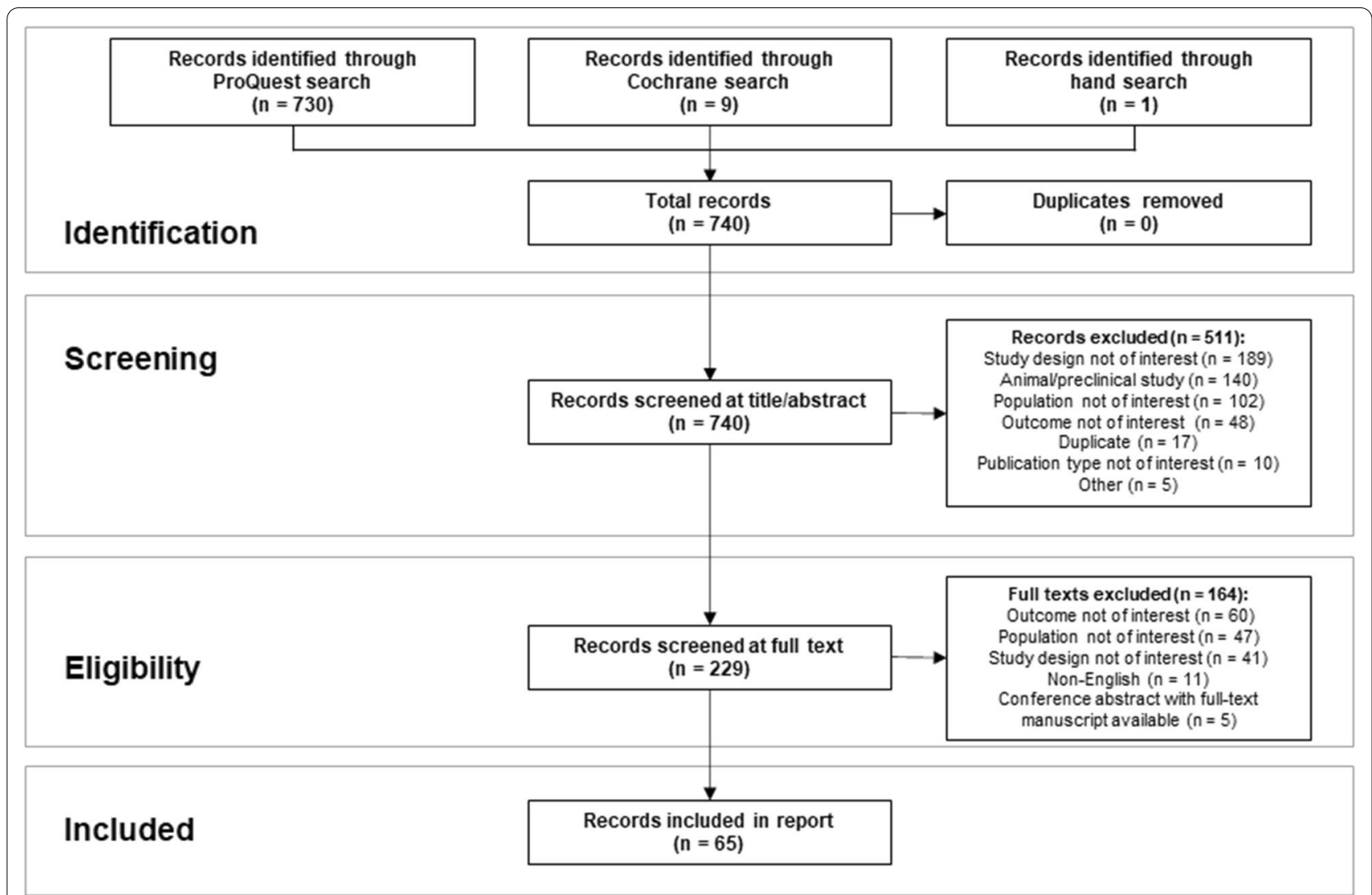

Fig. 1 PRISMA study identification flow chart. PRISMA, Preferred reporting items for systematic review and meta-analyses

\section{Methods}

The systematic literature review was conducted in accordance with Preferred Reporting Items for Systematic Review and Meta-Analyses guidelines [15]. The literature review was developed based on a predefined search and selection protocol. Search terms are provided in Additional file 1: Table S1. The search focused on relevant studies published as journal articles or conference abstracts through April 2, 2020 in MEDLINE and Embase (searched via ProQuest), written in English.

Studies comprised of $\geq 80 \%$ patients with RDEB from any country were included. Observational studies (retrospective or prospective) including cohort, case-control, cross sectional studies, and case series and trials were included. Case reports (sample size $<$ five patients), notes, editorials, and commentaries were excluded. Systematic reviews were included for the purpose of identification of primary studies. Animal and preclinical studies were excluded.

An experienced reviewer (EL, ST) independently screened all titles and abstracts resulting from the search methodology to identify articles for full-text review.
Citations selected for full-text review were screened by the same reviewer for potential inclusion into the data extraction file and report. A second reviewer (EL, ST) verified the results of the title/abstract screening and fulltext review. A standardized table was used to extract and record relevant data from selected publications.

\section{Results}

\section{Summary of included studies}

A total of 740 citations were identified, of which 229 full texts were screened and 65 were included within this review (56 manuscripts; nine conference abstracts or presentations) (Fig. 1; Additional file 1: Table S2). The majority of studies included all ages ( $\mathrm{n}=36$ studies), or children ( $n=20$ studies); one study was in an adult-only cohort, and eight did not report age. The average age ranged between three years to 30 years of age at the time of the study. Most patients had severe or intermediate subtypes; the proportion of patients with severe RDEB included in the identified studies ranged from 26 to $100 \%$. 
Table 1 Incidence of symptoms in patients with RDEB

\begin{tabular}{|c|c|c|c|}
\hline Symptom & $\%$ & $\mathrm{n} / \mathrm{N}$ & Design, country \\
\hline \multicolumn{4}{|l|}{ Blisters/lesions } \\
\hline \multirow[t]{3}{*}{ Blisters at or within 1 week of birth } & 94 & $15 / 16$ & Registry analysis, Australia/NZ [35] \\
\hline & 86 & $12 / 14$ & Registry analysis, UK [33] \\
\hline & 70 & $7 / 10$ & Single-center, Saudi Arabia [16] \\
\hline \multicolumn{4}{|l|}{ Orallesions } \\
\hline \multirow[t]{4}{*}{ Any oral lesions } & 100 & $35 / 35^{\mathrm{a}}$ & Multicenter, Spain [48] \\
\hline & 92 & $33 / 35^{b}$ & Multicenter, Spain [48] \\
\hline & 89 & $8 / 9^{c}$ & Registry analysis, UK [33] \\
\hline & 79 & $22 / 28$ & Single-center, Japan [43] \\
\hline Lingual lesions & 77 & $27 / 35$ & Multicenter, Spain [48] \\
\hline Dental lesions & 61 & $17 / 28$ & Single-center, Japan [43] \\
\hline Soft palate lesions & 60 & $21 / 35$ & Multicenter, Spain [48] \\
\hline Oral bullae & 59 & $10 / 17^{d}$ & Case-review, Serbia [21] \\
\hline Lesions on lips, mouth, tongue or ear & 53 & $32 / 60$ & Single-center, Brazil [22] \\
\hline Hard palate lesions & 53 & $18 / 35$ & Multicenter, Spain [48] \\
\hline Labial lesions & 46 & $16 / 35$ & Multicenter, Spain [48] \\
\hline Palatal milium cysts & 46 & $16 / 35$ & Multicenter, Spain [48] \\
\hline Jugal mucosa & 34 & $12 / 35$ & Multicenter, Spain [48] \\
\hline \multicolumn{4}{|l|}{ Otherlesions } \\
\hline Nail lesions & 75 & $21 / 28$ & Single-center, Japan [43] \\
\hline Lip lesions & 53 & $32 / 60$ & Single-center, Brazil [22] \\
\hline Esophageal lesions & 47 & $28 / 60$ & Single-center, Brazil [22] \\
\hline Nostril lesions & 18 & $11 / 60$ & Single-center, Brazil [22] \\
\hline Eyelid blisters & 7 & $5 / 72$ & Single-center, UK [51] \\
\hline External ear canal lesions & 3 & $2 / 60$ & Single-center, Brazil [22] \\
\hline Larynx lesions & 2 & $1 / 60$ & Single-center, Brazil [22] \\
\hline \multicolumn{4}{|l|}{ Strictures/stenoses } \\
\hline \multirow[t]{6}{*}{ Esophageal strictures/stenosis } & 86 & $6 / 7$ & Single-center, US [52] \\
\hline & 81 & $43 / 53$ & Survey, US [53] \\
\hline & 65 & $37 / 57$ & Single-center, UK [31] \\
\hline & 64 & $100 / 157$ & Single-center, Germany [55] \\
\hline & 64 & $53 / 83$ & Survey, International [54] \\
\hline & 51 & $216 / 424$ & Registry analysis, US [30] \\
\hline \multicolumn{4}{|l|}{ Other strictures/stenoses } \\
\hline Anal strictures & 15 & $62 / 422$ & Registry analysis, US [30] \\
\hline Pulmonary artery stenosis & 14 & $1 / 7$ & Single-center, US [52] \\
\hline Nostril stenoses & 5 & $3 / 60$ & Single-center, Brazil [22] \\
\hline Urethral meatal stenoses & 3 & $14 / 425$ & Registry analysis, US [27] \\
\hline Anterior commissure stenoses & 2 & $1 / 60$ & Single-center, Brazil [22] \\
\hline Pyloric stenoses or atresia & 1 & $5 / 419$ & Registry analysis, US [30] \\
\hline Laryngeal stenoses & 0.7 & $3 / 412$ & Registry analysis, US [29] \\
\hline Rectal strictures & 0.2 & $1 / 422$ & Registry analysis, US [30] \\
\hline \multicolumn{4}{|l|}{ Malnutrition/failure to thrive } \\
\hline \multirow[t]{2}{*}{ Malnutrition/nutritional problems } & 72 & $38 / 53$ & Survey, US [53] \\
\hline & 50 & $12 / 24$ & Single-center, France [20] \\
\hline \multirow[t]{2}{*}{ Failure to thrive } & 39 & $22 / 57$ & Single-center, UK [31] \\
\hline & 25 & $21 / 83$ & Survey, International [54] \\
\hline Growth problems diagnosed by physician & 34 & $18 / 53$ & Survey, US [53] \\
\hline Negative height standard deviation scores & 94 & $17 / 18$ & Single-center, UK [44] \\
\hline
\end{tabular}


Table 1 (continued)

\begin{tabular}{|c|c|c|c|}
\hline Symptom & $\%$ & $n / N$ & Design, country \\
\hline Negative height velocity standard deviation scores & 89 & $16 / 18$ & Single-center, UK [44] \\
\hline \multicolumn{4}{|l|}{ Nutritional deficiencies } \\
\hline Selenium deficiency & 94 & NR & Single-center, Germany [55] \\
\hline Vitamin D deficiency & 67 & NR & Single-center, Germany [55] \\
\hline Low albumin levels & 56 & NR & Single-center, Germany [55] \\
\hline Zinc deficiency & 55 & NR & Single-center, Germany [55] \\
\hline \multicolumn{4}{|l|}{ Anemia } \\
\hline \multirow[t]{7}{*}{ Any anemia } & 100 & $10 / 10$ & Single-center, Saudi Arabia [16] \\
\hline & 91 & $143 / 157$ & Single-center, Germany [55] \\
\hline & 76 & $40 / 53$ & Survey, US [53] \\
\hline & 68 & $17 / 25$ & Registry, Australia [34] \\
\hline & 60 & $47 / 79$ & Registry, UK [17] \\
\hline & 52 & $43 / 83$ & Survey, International [54] \\
\hline & 50 & $3 / 6$ & Single-center, US [52] \\
\hline \multicolumn{4}{|l|}{ Pseudosyndactyly } \\
\hline \multirow[t]{3}{*}{ Any pseudosyndactyly } & 71 & $5 / 7$ & Single-center, Japan [43] \\
\hline & 50 & $14 / 28$ & Single-center, US [52] \\
\hline & 22 & $2 / 9$ & Single-center, Saudi Arabia [16] \\
\hline Pseudosyndactyly of foot & 55 & $46 / 83$ & Survey, International [54] \\
\hline \multirow[t]{2}{*}{ Pseudosyndactyly of hand } & 65 & NR/425 & Registry, US [28] \\
\hline & 13 & $11 / 83$ & Survey, International [54] \\
\hline \multicolumn{4}{|l|}{ Ocular symptoms } \\
\hline \multirow[t]{4}{*}{ Any ocular symptoms } & 68 & $36 / 53$ & Survey, US [53] \\
\hline & 52 & $16 / 31$ & NR, Chile [42] \\
\hline & 52 & $43 / 83$ & Survey, International [54] \\
\hline & 51 & $37 / 72$ & Single-center, UK [51] \\
\hline \multirow[t]{3}{*}{ Corneal complications in those with ocular symptoms } & 100 & $16 / 16$ & NR, Chile [42] \\
\hline & 68 & $25 / 37$ & Single-center, UK [51] \\
\hline & 63 & $5 / 8^{c}$ & Registry analysis, UK [33] \\
\hline \multicolumn{4}{|l|}{ Other ocular symptoms in those experiencing ocular involvement } \\
\hline Anterior blepharitis and collarettes & 94 & $15 / 16$ & NR, Chile [42] \\
\hline Corneal erosions & 63 & $5 / 8^{c}$ & Registry analysis, UK [33] \\
\hline Symblepharon & 59 & $8 / 16$ & NR, Chile [42] \\
\hline \multirow[t]{2}{*}{ Ectropion } & 38 & $6 / 16$ & NR, Chile [42] \\
\hline & 13 & $1 / 8^{c}$ & Registry analysis, UK [33] \\
\hline Conjunctival complications & 14 & $5 / 37$ & Single-center, UK [51] \\
\hline Exposure keratitis associated with upper and lower eyelid extropian's & 8 & $3 / 37$ & Single-center, UK [51] \\
\hline \multicolumn{4}{|l|}{ Other commonly reported symptoms } \\
\hline \multirow[t]{2}{*}{ Nail dystrophy and loss } & 100 & $10 / 10$ & Single-center, Saudi Arabia [16] \\
\hline & 100 & $12 / 12$ & Registry analysis, UK [33] \\
\hline \multirow[t]{3}{*}{ Milia } & 100 & $9 / 9$ & Single-center, Saudi Arabia [16] \\
\hline & 93 & $49 / 53$ & Survey, US [53] \\
\hline & 21 & $6 / 28$ & Single-center, Japan [43] \\
\hline \multirow[t]{4}{*}{ Constipation } & 75 & $9 / 12$ & Registry, UK [33] \\
\hline & 72 & $38 / 53$ & Survey, US [53] \\
\hline & 60 & $254 / 422$ & Registry analysis, US [30] \\
\hline & 40 & $23 / 57$ & Single-center, UK [31] \\
\hline
\end{tabular}


Table 1 (continued)

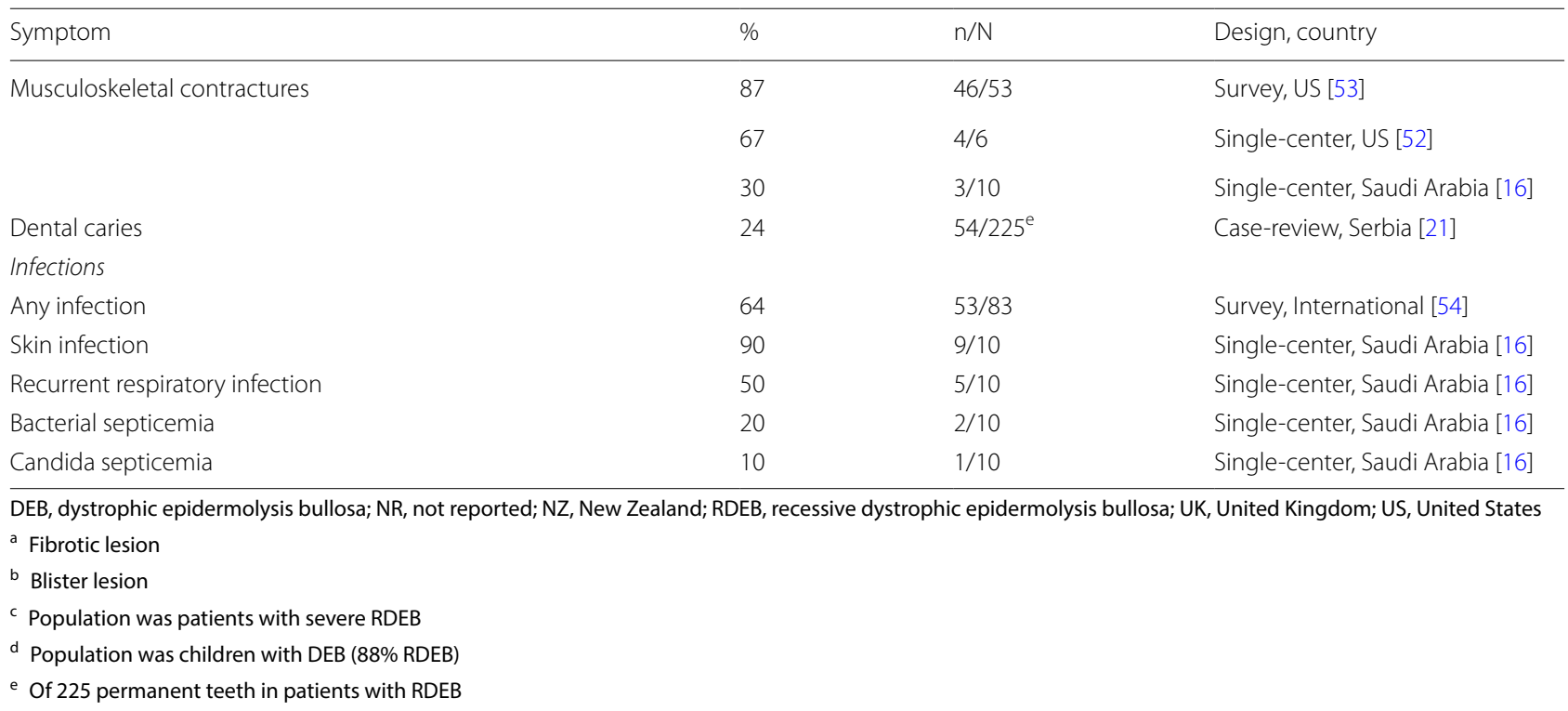

\section{Clinical burden Symptoms}

Forty-one studies reported on symptom prevalence (Table 1) and/or burden [16-56]. Seven studies reported on the cumulative risk of symptoms at different ages including data from the US National EB Registry and Australasian EB Registry (Table 2) [6, 25-30].

\section{Wound burden}

A US single-center study of 40 RDEB patients reported the clinical differences between recurrent or chronic open wounds [56]. Recurrent wounds healed but blistered again easily while chronic wounds remained open for 12 weeks or longer. Chronic wounds were significantly larger than recurrent wounds $\left(66.3 \mathrm{~cm}^{2}\right.$ vs. 44.7 $\left.\mathrm{cm}^{2} ; p<0.01\right)$ and more painful (4.31 of 10 points vs. 3.59; $p=0.05)$. Larger wound size was correlated with increased pain and itch among both chronic and recurrent wounds.

Results from a global registry survey of 85 RDEB patients with a total of 937 recurrent wounds and 289 chronic wounds reported a mean of 3 (SD, 2) chronic wounds and 11 (SD, 10) recurrent wounds per patient [54]. Recurrent wounds tended to be small $(<2.5 \mathrm{~cm}$ diameter; $491 / 937,52 \%)$ or medium sized $(2.5-7.5 \mathrm{~cm}$; $355 / 937,38 \%)$ rather than large $(>7.5 ; 91 / 937,10 \%)$, while chronic wounds were generally evenly distributed between sizes (small: 88/289, 30\%; medium: 103/289, $36 \%$; large: $98 / 289,34 \%)$. The majority of recurrent wounds took $0-1$ weeks $(197 / 937,21 \%)$ or $1-3$ weeks $(702 / 937,75 \%)$ to close while chronic wounds never closed $(289 / 289,100 \%)$. In a separate US survey, the majority of patients $(\mathrm{N}=19)$ and caregivers $(\mathrm{N}=34)$ reported that wounds covered more than $30 \%$ of the body $(32 / 53,60 \%)$; [53] 28\% (15/53) reported wounds covering $10-30 \%$ of the body and only $11 \%(6 / 53)$ reported wounds covering less than $10 \%$ of the body.

In three studies of neonates with RDEB, the vast majority of infants developed blisters within one week of birth (range of $70 \%$ to $94 \%$; Table 1) [16, 33, 35]. Five studies reported on the incidence of oral blisters or lesions in patients with $\mathrm{RDEB}[21,22,33,43,48]$. The proportion of patients experiencing these lesions ranged from 79 to $100 \%$ [33, 43, 48]. Blisters and lesions of the nail, lip, esophagus, nostril, eyelid, ear canal, or larynx were reported in three studies $[22,43,51]$.

\section{Pain and itch}

The burden of pain and itch was reported in seven studies [53, 54, 57-61], 5 of which utilized patient-reported outcome measures (PROMs, Table 5) [53, 57-60]. Patients with RDEB reported high levels of pain and pruritus compared to patients with DDEB, epidermolysis bullosa simplex (EBS), and other skin diseases [53, 57-60]. In a US survey study, patients with RDEB $(\mathrm{N}=32)$ ranked the top three most bothersome symptoms to be skin lesions and blisters $(7 / 32[23 \%])$, itching (5/32 [16\%]), and pain (5/32 [16\%]) [61]. A global survey of 83 patients with RDEB found that the majority of patients experienced itch $(72 / 83,85 \%)$, and presence of itch did not differ by patient-reported skin disease severity [54]. The worst pain experienced over the previous 12 months also did not differ by patient-reported skin disease severity in this cohort. Patients with RDEB assessing their pain via the 
Table 2 Cumulative risk of symptoms over time in patients with RDEB

\begin{tabular}{|c|c|c|c|c|c|c|c|c|c|}
\hline \multirow[t]{2}{*}{ Symptom, study } & \multirow{2}{*}{$\begin{array}{l}\text { Country, registry (date of } \\
\text { data collection) }\end{array}$} & \multirow[t]{2}{*}{ RDEB population (N) } & \multirow{2}{*}{$\begin{array}{l}\text { Overall } \\
\text { incidence } \\
(\%)\end{array}$} & \multicolumn{6}{|c|}{ Cumulative risk (\%) at } \\
\hline & & & & 1 year & 10 years & 15 years & 20 years & 40 years & 60 years \\
\hline \multicolumn{10}{|l|}{ General symptoms } \\
\hline $\begin{array}{l}\text { Esophageal stenoses and } \\
\text { strictures }\end{array}$ & US, NEBR (1986-2002) & Severe (134) & 79 & 7 & 57 & 72 & 79 & 89 & 95 \\
\hline \multirow[t]{2}{*}{ Fine [30] } & & Intermediate (261) & 37 & 4 & 27 & 34 & 40 & 62 & 70 \\
\hline & & Inversa (15) & 87 & 0 & 33 & 56 & 56 & 89 & $N R$ \\
\hline $\begin{array}{l}\text { Laryngeal stenoses and } \\
\text { strictures }\end{array}$ & US, NEBR (1986-2002) & Severe (138) & 2 & 0 & 1 & 1 & 1 & 5 & 5 \\
\hline \multirow[t]{2}{*}{ Fine [29] } & & Intermediate (263) & 0 & 0 & 0 & 0 & 0 & 0 & 0 \\
\hline & & Inversa (17) & 0 & 0 & 0 & 0 & 0 & 0 & 0 \\
\hline $\begin{array}{l}\text { Pseudosyndactyly of the } \\
\text { hands }\end{array}$ & US, NEBR (1986-2002) & Severe (142) & 95 & 16 & 92 & 93 & 98 & 98 & 98 \\
\hline \multirow[t]{2}{*}{ Fine $[28]$} & & Intermediate (266) & 51 & 13 & 43 & 49 & 50 & 55 & 55 \\
\hline & & Inversa (17) & 41 & 0 & 8 & 26 & 26 & 26 & 26 \\
\hline $\begin{array}{l}\text { Musculoskeletal contrac- } \\
\text { tures }\end{array}$ & US, NEBR (1986-2002) & Severe (142) & NR & 13 & 83 & 92 & 99 & $N R$ & NR \\
\hline \multirow[t]{2}{*}{ Fine $[28]$} & & Intermediate (266) & $N R$ & 4 & 37 & 46 & 46 & 49 & 78 \\
\hline & & Inversa (17) & $N R$ & 0 & 8 & 25 & 25 & 43 & $N R$ \\
\hline CHF or cardiomyopathy & US, NEBR ${ }^{\mathrm{a}}(1986-2002)$ & Severe (140) & 7 & 1 & 2 & 4 & 7 & 19 & 19 \\
\hline Fine $[25]$ & & Intermediate (267) & 1 & 0 & 0 & 0 & 1 & 3 & 3 \\
\hline Growth retardation & US, NEBR (1986-2002) & Severe (141) & $N R$ & 14 & 67 & 75 & 80 & 80 & NR \\
\hline \multirow[t]{2}{*}{ Fine [30] } & & Intermediate (266) & $N R$ & 3 & 10 & 12 & 13 & 13 & 13 \\
\hline & & Inversa (17) & NR & 6 & 20 & 20 & 20 & 20 & $N R$ \\
\hline \multicolumn{10}{|l|}{ Premature mortality } \\
\hline Death from sepsis & US, NEBR ${ }^{b}$ (1986-2002) & Intermediate (262) & NR & 0.4 & 0.4 & 0.4 & NR & $N R$ & $N R$ \\
\hline \multicolumn{10}{|l|}{ Fine [63] } \\
\hline Death from pneumonia & US, NEBR (1986-2002) & Severe (138) & $N R$ & 0 & 0 & 1.8 & NR & $N R$ & NR \\
\hline \multirow[t]{2}{*}{ Fine $[63]$} & & Intermediate (262) & NR & 0.4 & 0.4 & 1.1 & NR & $N R$ & $N R$ \\
\hline & & Inversa (17) & 0 & 0 & 0 & 0 & NR & $N R$ & $N R$ \\
\hline $\begin{array}{l}\text { Death from respiratory } \\
\text { failure }\end{array}$ & US, NEBR ${ }^{\mathrm{a}}(1986-2002)$ & Severe (138) & NR & 0 & 0 & 0.4 & NR & NR & NR \\
\hline Fine [63] & & Intermediate (262) & $N R$ & NR & NR & 1.1 & NR & NR & $N R$ \\
\hline Death from renal failure & US, NEBR (1986-2002) & All RDEB (417) & NR & 0 & 0 & 0 & NR & $N R$ & $N R$ \\
\hline \multicolumn{10}{|l|}{ Fine [63] } \\
\hline $\begin{array}{l}\text { Death from failure to } \\
\text { thrive }\end{array}$ & US, NEBR (1986-2002) & All RDEB (417) & NR & 0 & 0 & 0 & NR & $N R$ & NR \\
\hline \multicolumn{10}{|l|}{ Fine [63] } \\
\hline Death from SCC & US, NEBR (1986-2002) & All RDEB (417) & NR & 0 & 0 & 0 & NR & $N R$ & NR \\
\hline \multicolumn{10}{|l|}{ Fine [63] } \\
\hline \multicolumn{10}{|l|}{ SCC-related } \\
\hline Development of SCC & UK, NEBR (2000-2015) & Children (79) & 0 & NR & $N R$ & NR & NR & $N R$ & NR \\
\hline \multicolumn{10}{|l|}{ Alband [17] } \\
\hline \multirow{2}{*}{$\begin{array}{l}\text { Development of SCC } \\
\text { Bruckner [53] }\end{array}$} & US, Survey (2017) & $\begin{array}{l}\text { Children (caregiver- } \\
\text { reported) (34) }\end{array}$ & 0 & NR & NR & NR & NR & $N R$ & NR \\
\hline & & Adults (19) & 16 & $N R$ & $N R$ & $N R$ & $N R$ & $N R$ & $N R$ \\
\hline \multirow{2}{*}{$\begin{array}{l}\text { Development of SCC } \\
\text { Kim [6] }\end{array}$} & \multirow{2}{*}{$\begin{array}{c}\text { Australia, AEBR } \\
(2009-2016)\end{array}$} & Severe (11) & NR & $N R$ & $N R$ & $N R$ & 26 & $76^{c}$ & $N R$ \\
\hline & & Intermediate (5) & $N R$ & $N R$ & $N R$ & $N R$ & $N R$ & $10^{c}$ & $67^{d}$ \\
\hline Development of SCC & US, NEBR (1986-2002) & Severe (141) & 23 & 0 & 0 & 0 & 8 & 74 & $N R$ \\
\hline Fine $[26]$ & & Intermediate (263) & 9 & 0 & 0 & 1 & 4 & 24 & 36 \\
\hline & & Inversa (17) & 18 & 0 & 0 & 0 & 0 & 8 & $N R$ \\
\hline
\end{tabular}


Table 2 (continued)

\begin{tabular}{|c|c|c|c|c|c|c|c|c|c|}
\hline \multirow[t]{2}{*}{ Symptom, study } & \multirow{2}{*}{$\begin{array}{l}\text { Country, registry (date of } \\
\text { data collection) }\end{array}$} & \multirow[t]{2}{*}{ RDEB population (N) } & \multirow{2}{*}{$\begin{array}{l}\text { Overall } \\
\text { incidence } \\
\text { (\%) }\end{array}$} & \multicolumn{6}{|c|}{ Cumulative risk (\%) at } \\
\hline & & & & 1 year & 10 years & 15 years & 20 years & 40 years & 60 years \\
\hline \multirow{2}{*}{$\begin{array}{l}\text { SCC-related death } \\
\text { Kim [6] }\end{array}$} & \multirow{2}{*}{$\begin{array}{c}\text { Australia, AEBR }{ }^{\mathrm{a}} \\
\quad(2009-2016)\end{array}$} & Severe (11) & NR & NR & NR & NR & $30^{e}$ & $84^{f}$ & NR \\
\hline & & Intermediate (5) & NR & NR & NR & NR & $N R$ & $17^{c}$ & $67^{9}$ \\
\hline \multirow{2}{*}{$\begin{array}{l}\text { SCC-related death (all } \\
\text { patients with RDEB) }\end{array}$} & \multirow[t]{3}{*}{ US, NEBR (1986-2002) } & Severe (141) & NR & 0 & 0 & 0 & 1 & 59 & $N R$ \\
\hline & & Intermediate (263) & NR & 0 & 0 & 0 & 0 & 8 & 22 \\
\hline Fine [26] & & Inversa (17) & NR & 0 & 0 & 0 & 0 & 0 & NR \\
\hline $\begin{array}{l}\text { SCC-related death (his- } \\
\text { tory of SCC) }\end{array}$ & \multirow[t]{3}{*}{ US, NEBR (1986-2002) } & Severe (32) & NR & 0 & 0 & 0 & 13 & 81 & NR \\
\hline \multirow[t]{2}{*}{ Fine [26] } & & Intermediate (24) & NR & 0 & 0 & 4 & 4 & 31 & 60 \\
\hline & & Inversa (3) & NR & 0 & 0 & 0 & 0 & 0 & NR \\
\hline
\end{tabular}

AEBR, Australasian Epidermolysis Bullosa Registry; CHF, congestive heart failure; NEBR, National Epidermolysis Bullosa Registry; NR, not reported; RDEB, recessive dystrophic epidermolysis bullosa; SCC, squamous cell carcinoma; US, United States

a Data not available in inversa subtype

b Data not available in severe or inversa subtype

c 35 years

d 65 years

e 25 years

f 34 years

g 52 years

Pain Quality Assessment Scale (PQAS) noted the highest scores (indicating increased pain/sensation) for unpleasant, sharp, intense, and tender pain [60].

\section{Strictures and stenoses}

In six studies, the proportion of patients with esophageal strictures ranged from 51 to $86 \%$ [30, 31, 52-55]. A Mexican analysis of 14 patients reported a median of one stenosis per year, with $74 \%$ (14/19 stenoses) in the proximal region [32]. A single-center UK study of 57 patients with stenoses reported a median of two stricture sites at esophageal dilation, the majority of which were located in the cervical or thoracic region (percentage not given) [41]. A single-center study in Croatia reported that in six patients, each with a stenosis, $83 \%$ (5/6 stenoses) were located in the upper third of the esophagus, with the remaining stenosis in the lower third [40].

Strictures and stenoses of the anus, pulmonary artery, nostril, urethra, anterior commissure, pylorus, larynx, and rectum were reported in $0.2 \%$ to $15 \%$ of patients with RDEB in five studies (Table 1) [22, 27, 29, 30, 52]. In two analyses of the US National EB Registry $(\mathrm{N}=422-425)$, the lifetime cumulative risk of esophageal strictures was much higher than risk of laryngeal stenoses and strictures (Table 2) $[29,30]$. Risk was higher in the severe subtype than the intermediate or inversa subtypes.

\section{Malnutrition/failure to thrive}

The proportion of patients with malnutrition/failure to thrive ranged from 25 to $72 \%$ while negative height and height velocity standard deviation scores were $94 \%$ and $89 \%$ (Table 1) [20, 31, 44, 53, 54]. In a UK analysis of 57 patients, etiologies of failure to thrive included reduction in dietary intake (due to dental involvement, pain from oral lesions), esophageal strictures, and heightened nutritional requirements secondary to extensive skin involvement [31]. A retrospective study of 157 German patients reported that approximately $50 \%$ of children with RDEB (exact numbers not reported) showed wasting (defined as weight below the third percentile) after the age of eight, and approximately $50 \%$ of children showed stunting (defined as height below the third percentile) after the age of ten; body mass index (BMI) in patients with RDEB fell in the underweight category $\left(<18.5 \mathrm{~kg} / \mathrm{m}^{2}\right)$, with a median BMI of $13.8 \mathrm{~kg} / \mathrm{m}^{2}$ in men and $15.7 \mathrm{~kg} /$ $\mathrm{m}^{2}$ in women 20 years of age [55]. The nutritional characteristics of 12 patients with RDEB undergoing gastrostomy were described in a French, single-center study. Within the cohort, the mean estimated oral energy intake as a percentage of the recommended dietary allowance (adjusted for age and sex) was 56\% (SD, 18) at time of gastrostomy feeding onset [20].

\section{Anemia}

The proportion of RDEB patients experiencing anemia ranged from 50 to $100 \%$ (Table 1), reported in seven studies $[16,17,34,52-55]$. Mean hemoglobin levels ranged from 8.8. to 12.3 (Table 3) [34, 55, 62]. Analysis of 25 RDEB patients captured in the Australasian EB Registry 
Table 3 Anemia-related laboratory findings in patients with RDEB

\begin{tabular}{|c|c|c|c|c|c|c|c|}
\hline References & Population (N) & $\begin{array}{l}\text { Mean (SD) } \\
\text { hemoglobin } \\
\text { (g/dL) }\end{array}$ & $\begin{array}{l}\text { Mean (SD) } \\
\text { reticulocytes } \\
\text { (\%) }\end{array}$ & $\begin{array}{l}\text { Mean (SD) ferritin } \\
(\mu \mathrm{g} / \mathrm{L})\end{array}$ & $\begin{array}{l}\text { Mean (SD) } \\
\text { transferrin } \\
\text { (mg/L) }\end{array}$ & $\begin{array}{l}\text { Mean (SD) } \\
\text { transferin } \\
\text { saturation (\%) }\end{array}$ & Mean $(S D)$ iron $(\mu \mathrm{g} / \mathrm{L})$ \\
\hline \multirow[t]{2}{*}{ Reimer [55] } & $\begin{array}{l}\text { Children with RDEB } \\
\text { (157) }\end{array}$ & $9.7(2.23)$ & $17.8(16.3)$ & $63.0(140.8)$ & $241.7(60.6)$ & $9.9(8.85)$ & $27.6(23.7)$ \\
\hline & Normal range (NA) & $12.55-16.55$ & $4.8-16.4$ & $22.5-275$ & $200-360$ & $16-45$ & $26-151.5$ \\
\hline Hwang [34] & $\begin{array}{l}\text { Children with RDEB } \\
\text { (NR) }\end{array}$ & $10.19(3.08)$ & NR & NR & NR & $N R$ & NR \\
\hline \multirow[t]{5}{*}{ Mellerio [62] } & $\begin{array}{l}\text { RDEB severe, } \\
0-16 \text { years (NR) }\end{array}$ & 10.84 (NR) & NR & NR & NR & NR & NR \\
\hline & $\begin{array}{l}\text { RDEB severe, } \\
17-25 \text { years (NR) }\end{array}$ & $12.30(\mathrm{NR})$ & NR & NR & NR & NR & NR \\
\hline & $\begin{array}{l}\text { RDEB severe, } \\
\text { 26-35 years (NR) }\end{array}$ & 11.09 (NR) & NR & NR & NR & NR & NR \\
\hline & $\begin{array}{l}\text { RDEB severe, } \\
36-45 \text { years (NR) }\end{array}$ & 8.80 (NR) & NR & NR & NR & NR & NR \\
\hline & $\begin{array}{l}\text { RDEB severe, } \\
46-55 \text { years (NR) }\end{array}$ & 9.30 (NR) & NR & NR & NR & NR & NR \\
\hline
\end{tabular}

NA, not applicable; NR, not reported; RDEB, recessive dystrophic epidermolysis bullosa

found that $88 \%(22 / 25)$ required intermittent iron or blood transfusions to elevate hemoglobin levels [34].

\section{Pseudosyndactyly}

The proportion of RDEB patients experiencing pseudosyndactyly ranged from 13 to $71 \%$ (Table 1), reported in three studies [16, 43, 52, 54]. The US National EB Registry reported the lifetime cumulative risk of pseudosyndactyly of the hands, which was highest in patients with the severe subtype (Table 2) [28].

\section{Microstomia}

The clinical burden of microstomia (abnormally small oral orifice) was reported in three studies [21, 48, 50]. A single-center case review of 17 Serbian patients up to age 21 years with DEB ( $88 \%$ RDEB) reported $77 \%$ of patients $(\mathrm{N}=13)$ had microstomia, with an average mouth opening capacity of $40.1 \mathrm{~mm}$ (SD, 6.6) [21]. A Spanish multicenter case review found an average oral aperture in RDEB patients $(\mathrm{N}=35)$ of $20.4 \mathrm{~mm}$, compared to an average of $46 \mathrm{~mm}$ in healthy controls $(\mathrm{N}=45)$ [48]. Eighty percent of RDEB patients had severe microstomia (oral aperture $\leq 30 \mathrm{~mm}$ ) and $20 \%$ had moderate microstomia (31-40 mm). No patients with RDEB had mild microstomia (41-50 $\mathrm{mm}$ ) or normal mouth opening size $(\geq 40 \mathrm{~mm})$. A Dutch single-center study reported $80 \%(8 / 10)$ of RDEB patients were unable to open their mouth wider than $35 \mathrm{~mm}$ [50]; the average maximal mouth opening in this patient cohort was $24.3 \mathrm{~mm}$ (SD, $11.6 \mathrm{~mm})$.

\section{Congestive heart failure and cardiomyopathy}

An international multicenter case review $(\mathrm{N}=13)$ reported a mean age of cardiomyopathy diagnosis of 12.6 years [39]. Notably, six (46\%) of these patients were deceased at the time of publication. Reported in 407 patients with RDEB included in the US National EB Registry, the cumulative risk of dilated cardiomyopathy and congestive heart failure tended to be low over the patient lifetime, though risk in patients with severe subtype increased with age (Table 2) [25].

\section{Ocular manifestations}

The clinical burden of ocular symptoms in RDEB include corneal complications and erosions, anterior blepharitis and collarettes, symblepharon, ectropion, conjunctival complications, and exposure keratitis (Table 1) [33, 42, $51,53]$. The proportion of patients experiencing ocular involvement ranged from 51 to $68 \%$ [42, 51, 53, 54]. Of patients with ocular symptoms, the proportion with corneal complications ranged from 63 to $100 \%$ [33, 42, 51]. Other ocular symptoms were reported in three studies $[33,42,51]$.

\section{Other common symptoms and complications}

Other commonly reported symptoms and complications, including nail dystrophy and loss, milia, dental caries, infections, constipation, and musculoskeletal contractures are reported in 12 studies (Table 1) $[16,17,20,21$, $30,31,33,34,43,52,53,55]$. 


\section{Premature mortality}

In a UK registry analysis of 79 patients with RDEB aged 16 and younger, nine children (11\%) died. Causes of death included sepsis and organ failure $(n=5)$, failure to thrive $(n=2)$, bowel perforation $(n=1)$, and preconditioning for bone marrow transplantation $(\mathrm{N}=1)$ [17]. The US National EB Registry analyzed the cumulative risk of childhood death from pneumonia, sepsis, respiratory failure, renal failure, and failure to thrive as in Table 2 [63].

\section{Squamous cell carcinoma}

Database analyses of the cumulative risk of developing SCC showed low risk during childhood and increases with age, with a high risk for development of and mortality from SCC by 40 years (Table 2) [6, 17, 26, 53, 63]. In data from the US National EB Registry, SCCs tended to develop in chronic skin wounds $(77.8 \%$ of SCC sites in 59 RDEB patients with SCC) [26]. The median number of SCC sites per patient was 3-3.5 (range: 1 to 40 sites). Median age at diagnosis, provided in a singlecenter study of 14 RDEB patients with SCC in Spain, was 24 years [64].

In an Australian registry analysis of patients with RDEB diagnosed with SCC $(\mathrm{N}=16)$, the median number of SCC sites per patient was 7 and ranged from 1 to 56 sites, with a median age of 29.5 years at first SCC [6]. The majority of SCCs (95\%; sample size not reported) developed on the extremities; $70 \%$ of those developed on the hands or feet. The site of SCC tended to be in areas of chronic ulcers and non-healing wounds, though percentages were not provided. Almost 70\% (11/16) of patients diagnosed with SCC experienced metastasis to regional lymph nodes (100\% of patients with metastasis, $10 / 10$ patients [data not available in one patient]), lungs $(80 \%$, $8 / 10)$, vertebrae $(30 \%, 3 / 10)$, and liver, adrenal gland, and muscle $(10 \%, 1 / 10)$ over the patient lifetime. Almost half of patients included in the study $(7 / 16,44 \%)$ underwent therapeutic amputation in their lifetime; median age at first amputation was 29 years.

In a single-center study in Spain, $35 \%$ of patients $(8 / 23)$ underwent amputation due to SCC [64]. In a study of 59 patients with RDEB and SCC, surgical amputation of at least one limb was performed in $21 \%$ of patients with the intermediate subtype to $42 \%$ with the severe subtype of patients (sample size of subtypes not reported) [26]. Amputation of the leg was most common (intermediate subtype, $67 \%$; severe subtype, $29 \%$ ), followed by arm (intermediate subtype, 33\%; severe subtype, 29\%), hand (intermediate subtype, NR; severe subtype, 29\%), and foot (intermediate subtype, NR; severe subtype, 14\%).

\section{Procedures}

Esophageal dilation and gastrostomy tube placement were the procedures most frequently reported upon in the literature. Ten studies reported on the use of esophageal dilations in patients with RDEB [17, 20, 23, 30, $40-42,55,65,66]$, and ten studies reported on the use of gastrostomy tubes (Table 4) [17, 23, 30, 31, 39, 49, 54, 55, $65,66]$. One single-center case review in the UK reported on treatment burden and satisfaction associated with gastrostomy tubes in RDEB $(\mathrm{N}=57)$ [65]. Two-thirds of children with RDEB (10/15) and all of their parents $(15 / 15)$ reported a satisfaction level with the gastrostomy tube of at least seven out of ten (indicating extreme satisfaction) over a median 8.9 years since placement. Almost half of patients $(7 / 15,47 \%)$ reported no gastrostomy site infections in the previous year; one-third reported fewer than two infections in the previous year $(5 / 15,33 \%)$. The remaining patients reported either $2-4$ infections $(n=2)$ or constant infections in the previous year $(n=1)$.

\section{Pseudosyndactyly release}

Three studies reported on pseudosyndactyly release of the hands or feet in patients with RDEB [23, 28, 66]. Within a US and Canadian cohort of 238 RDEB patients, $62(22 \%)$ underwent hand surgery. The median age for their first hand surgery was 8.1 years (IQR, 5.512.1 years; range, 3-25 years) [23]. Among 414 patients in the US National EB Registry, 151 (37\%) underwent mitten repair of the hands and 11 (3\%) underwent mitten repair of the feet [28]. The median number of hand surgeries performed was 3.0 (range: $1-22$ surgeries). Data on the median number of foot surgeries was not available. A retrospective analysis of 25 children with RDEB reported that $27 \%$ of patients (sample size not provided) underwent pseudosyndactyly release with or without skin graft [66].

\section{Diagnostic procedures}

Analysis of 283 RDEB patients in the EB Clinical Characterization and Outcomes Database reported that confirmatory diagnostic testing was performed in $77 \%$ $(218 / 283)$ of patients, and $63 \%(178 / 283)$ underwent multiple methods of diagnostic testing [23]. Of all RDEB patients, 65\% (184/283) underwent genetic analysis, 41\% (116/283) immunofluorescence, and 35\% (98/283) electron microscopy.

\section{Humanistic burden \\ Patient-reported outcome measures (PROMs)}

Eighteen studies utilized 16 distinct PROMs (Table 5) $[19,24,47,53,54,57-61,67-74]$. The most commonly used PROMs were the Quality of Life in Epidermolysis 
Table 4 Procedures in Patients with RDEB

\begin{tabular}{|c|c|c|}
\hline Variable & Data & Design, Country \\
\hline \multicolumn{3}{|l|}{ Esophageal dilation (ED) } \\
\hline \multirow[t]{6}{*}{ Proportion undergoing ED, \% (n/N) } & $74(23 / 31)$ & NR, Chile [42] \\
\hline & $56(157 / 283)$ & Registry analysis, US [23] \\
\hline & $43(34 / 79)$ & Registry analysis, UK [17] \\
\hline & $38\left(\mathrm{NR} / 25^{\mathrm{e}}\right)$ & Single-center, US [66] \\
\hline & $33(134 / 411)$ & Registry analysis, US [30] \\
\hline & $29(45 / 157)$ & Single-center, Germany [55] \\
\hline \multirow[t]{5}{*}{ Average EDs performed per patient, mean/median (N) } & Mean, 7 [14] & Single-center, UK [65] \\
\hline & Median, 6 (77) & Single-center, UK [41] \\
\hline & Median, 5 (17, inversa subtype) & Registry analysis, US [30] \\
\hline & Median, 3 (136, severe subtype) & \\
\hline & Median, 2 (258, intermediate subtype) & \\
\hline \multirow[t]{3}{*}{ Maximum number of EDs performed per patient, no $(\mathrm{N})$} & $14(14)$ & Single-center, UK [65] \\
\hline & $41(77)$ & Single-center, UK [41] \\
\hline & $50(411)$ & Registry analysis, US [30] \\
\hline Age at first ED, years $(N)$ & $5.5(77)$ & Single-center, UK [41] \\
\hline \multicolumn{3}{|l|}{ Gastrostomy tube } \\
\hline \multirow[t]{7}{*}{ Proportion undergoing GT, \% (n/N) } & $58(33 / 57)$ & Single-center, UK [31] \\
\hline & $37(104 / 283)$ & Registry analysis, US [23] \\
\hline & $33(27 / 83)$ & Survey, International [54] \\
\hline & $32(25 / 79)$ & Registry analysis, UK [17] \\
\hline & $24(97 / 412)$ & Registry analysis, US [30] \\
\hline & $14(22 / 157)$ & Single-center, Germany [55] \\
\hline & $8\left(2 / 25^{\mathrm{e}}\right)$ & Single-center, US [66] \\
\hline Average GTs performed per patient, median (N) & Median, 1 (412) & Registry analysis, US [30] \\
\hline Maximum GTs performed per patient, no (N) & $10(412)$ & Registry analysis, US [30] \\
\hline \multirow[t]{2}{*}{ Age at first $\mathrm{GT}$, years $(\mathrm{N})$} & $6\left(6^{a}\right)$ & Single-center, UK ${ }^{24}$ \\
\hline & $8\left(44^{\mathrm{a}}\right)$ & Single-center UK ${ }^{36}$ \\
\hline
\end{tabular}

ED, esophageal dilation; GT, gastrostomy tube; No, number; NR, not reported; RDEB, recessive dystrophic epidermolysis bullosa; UK, United Kingdom; US, United States

a Children with RDEB

Bullosa survey (QOLEB) [54, 59, 61, 69-71], the Visual Analogue Scale (VAS) for pain or pruritus [58, 59], and the instrument for scoring clinical outcomes of research for epidermolysis bullosa (iscorEB) [68, 72].

Patients with RDEB experienced significant impairment in overall quality of life (QOL) across multiple PROMs and domains (Table 5). RDEB patients had lower QOL than patients with other EB subtypes and patients with other skin diseases, especially compared with patients with more common diseases such as atopic dermatitis and psoriasis (Fig. 2).

\section{Functioning and social activities}

Patients with RDEB experienced limitations in functioning and social activities; many patients with RDEB required assistance or are unable to complete activities of daily living (Table 5). A US survey of RDEB patients $(\mathrm{N}=19)$ and caregivers of RDEB patients $(\mathrm{N}=34)$ reported an impact on the patient's ability to play $(50 / 53$, $94 \%)$, sleep $(47 / 53,89 \%)$, eat $(45 / 53,85 \%)$, move around the home $(44 / 53,83 \%)$, bathe or shower $(42 / 53,79 \%)$, shop $(33 / 53,62 \%)$, and write $(28 / 53,53 \%)$ due to their disease [53].

\section{Impact on families and caregivers}

The humanistic burden of disease extended beyond patients to affect their families. In a US study of parents of children with RDEB (sample size not provided), $90 \%$ reported that their ability to remain physically and emotionally close to their significant other was negatively impacted by their child's condition [75]. Additionally, over three-quarters (79\%) reported that their private life had suffered and $64 \%$ chose not to have more children due to their child's illness. Fifty-nine percent reported that their relationship was negatively affected by their child's illness, and $50 \%$ had little 
Tang et al. Orphanet J Rare Dis ～(2021) 16:175

Page 12 of 25

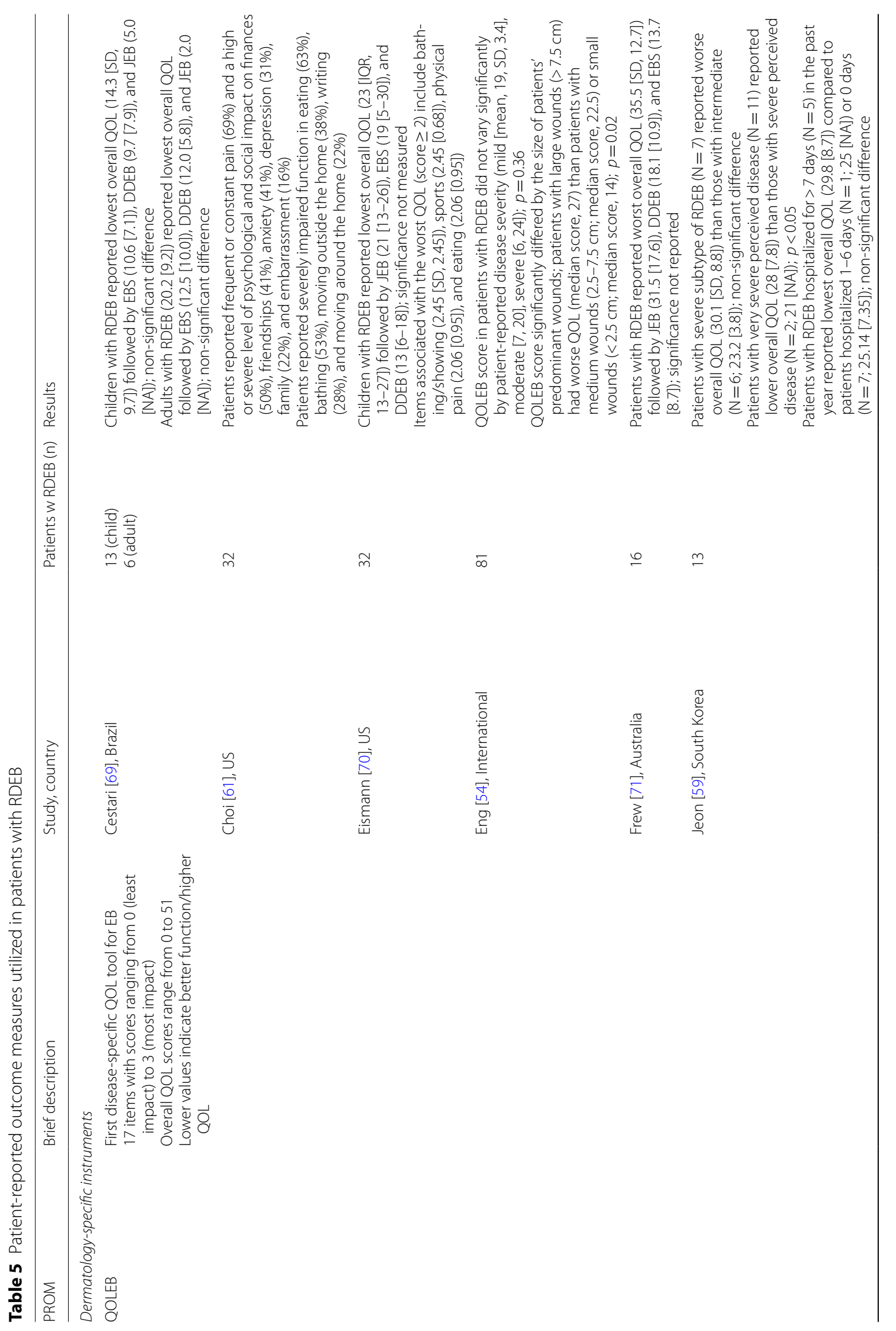




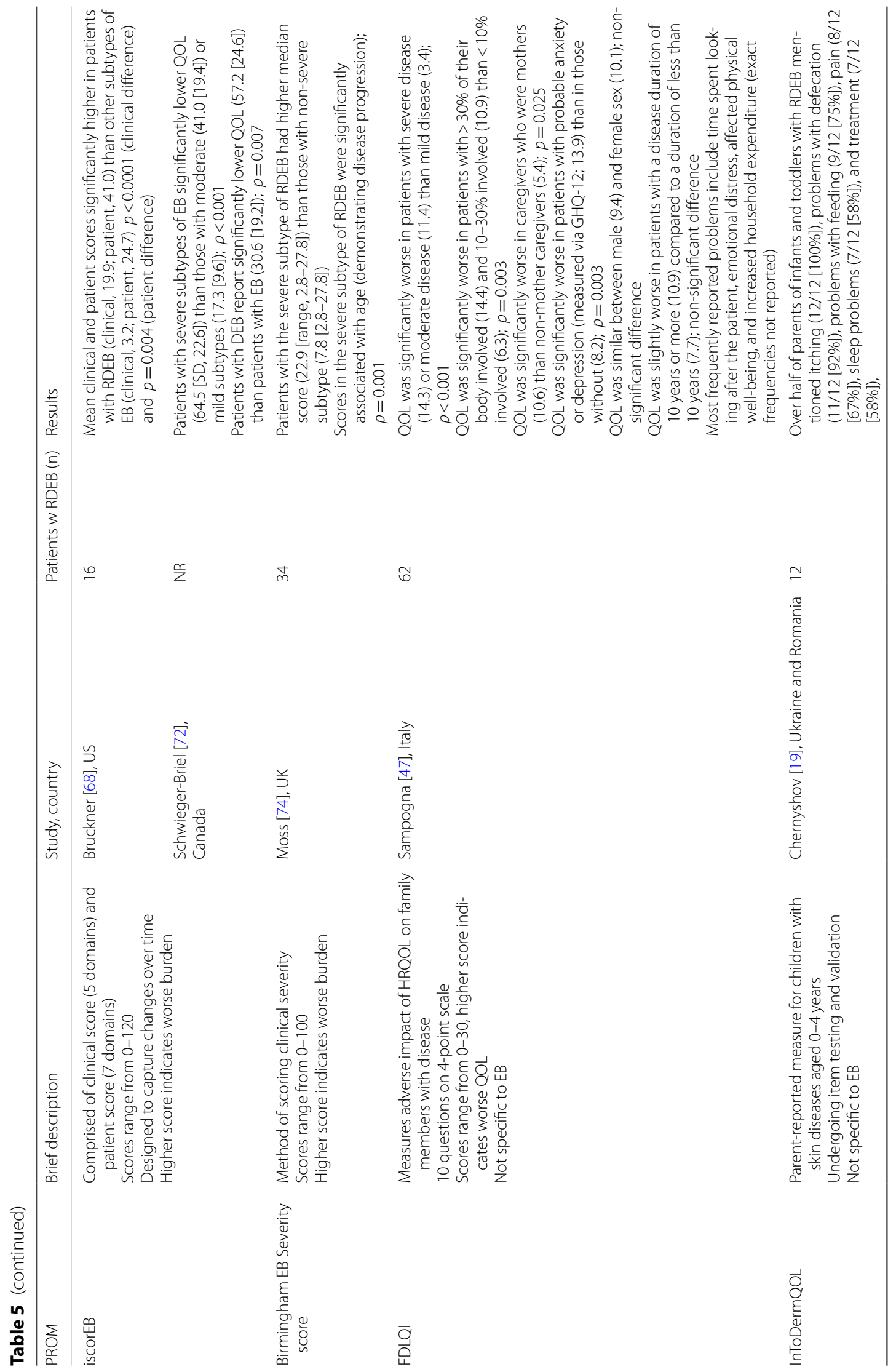




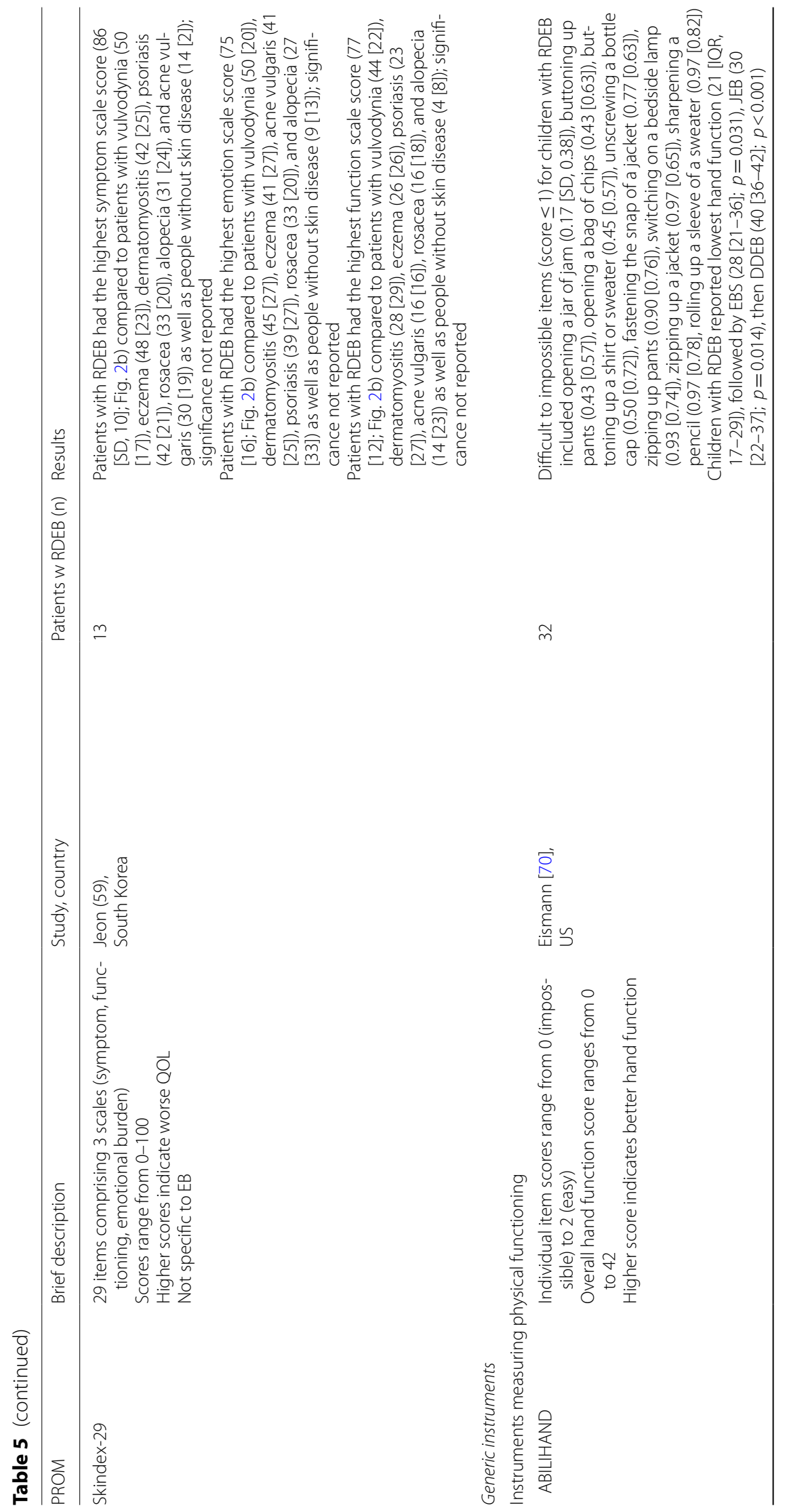




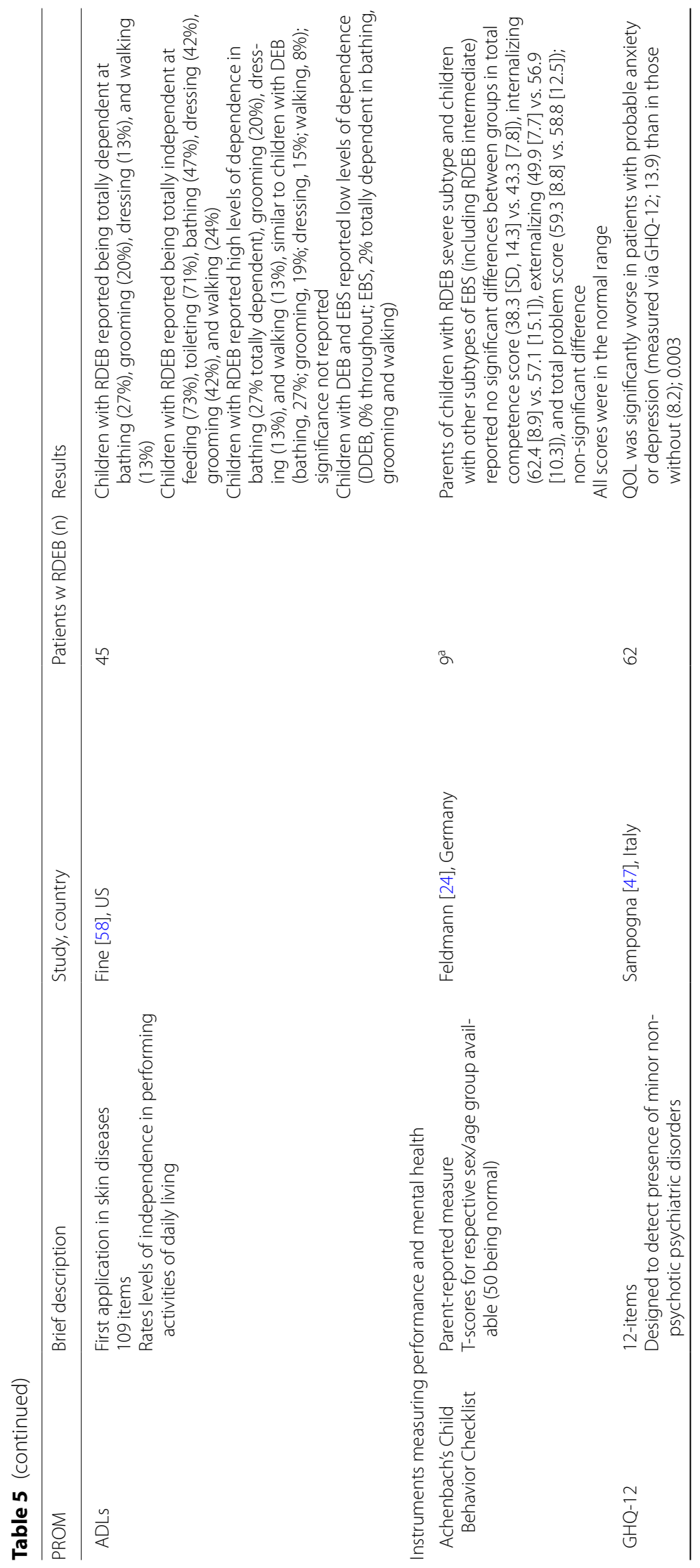


Tang et al. Orphanet J Rare Dis ～(2021) 16:175

Page 16 of 25

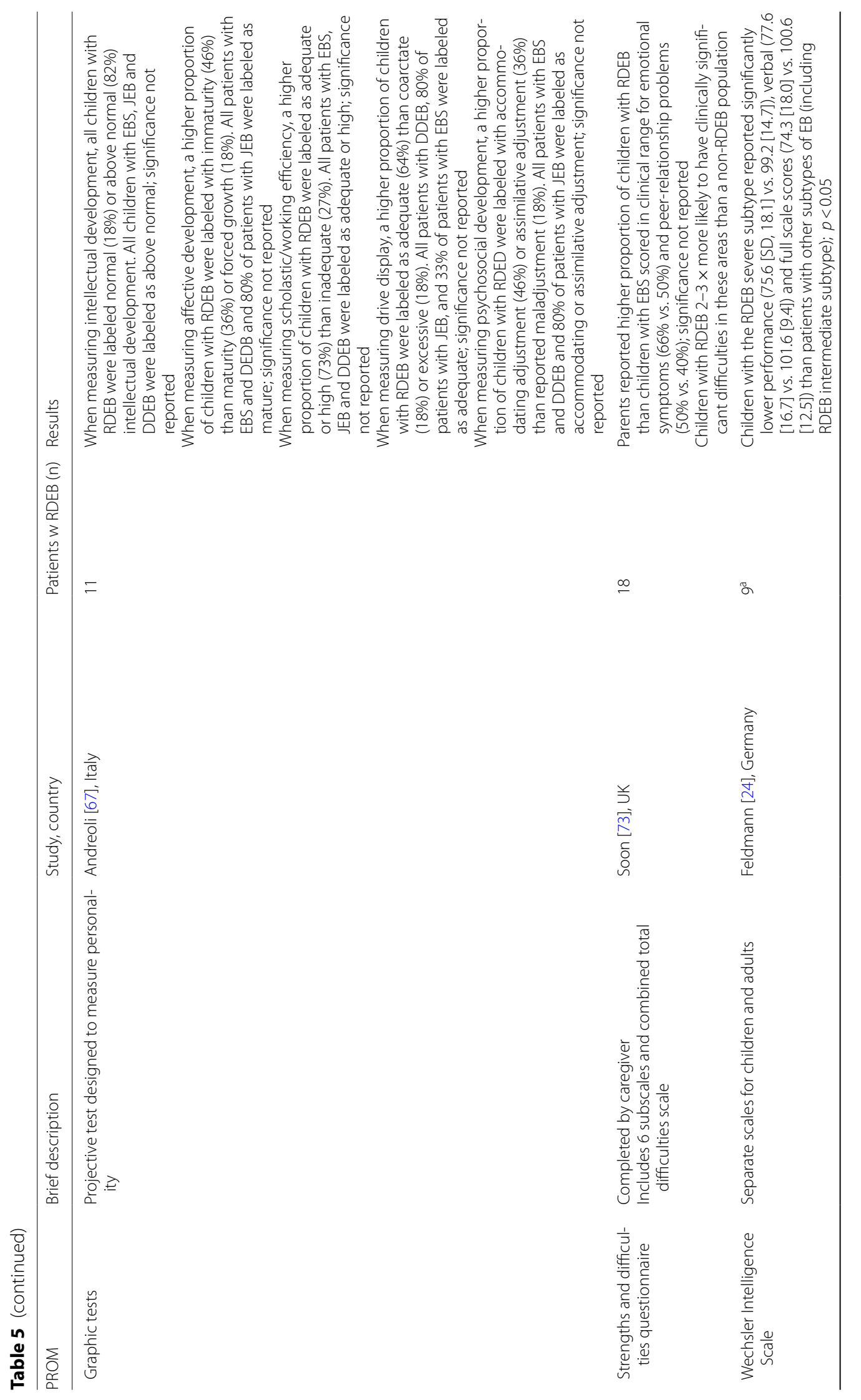


Tang et al. Orphanet J Rare Dis ～(2021) 16:175

Page 17 of 25

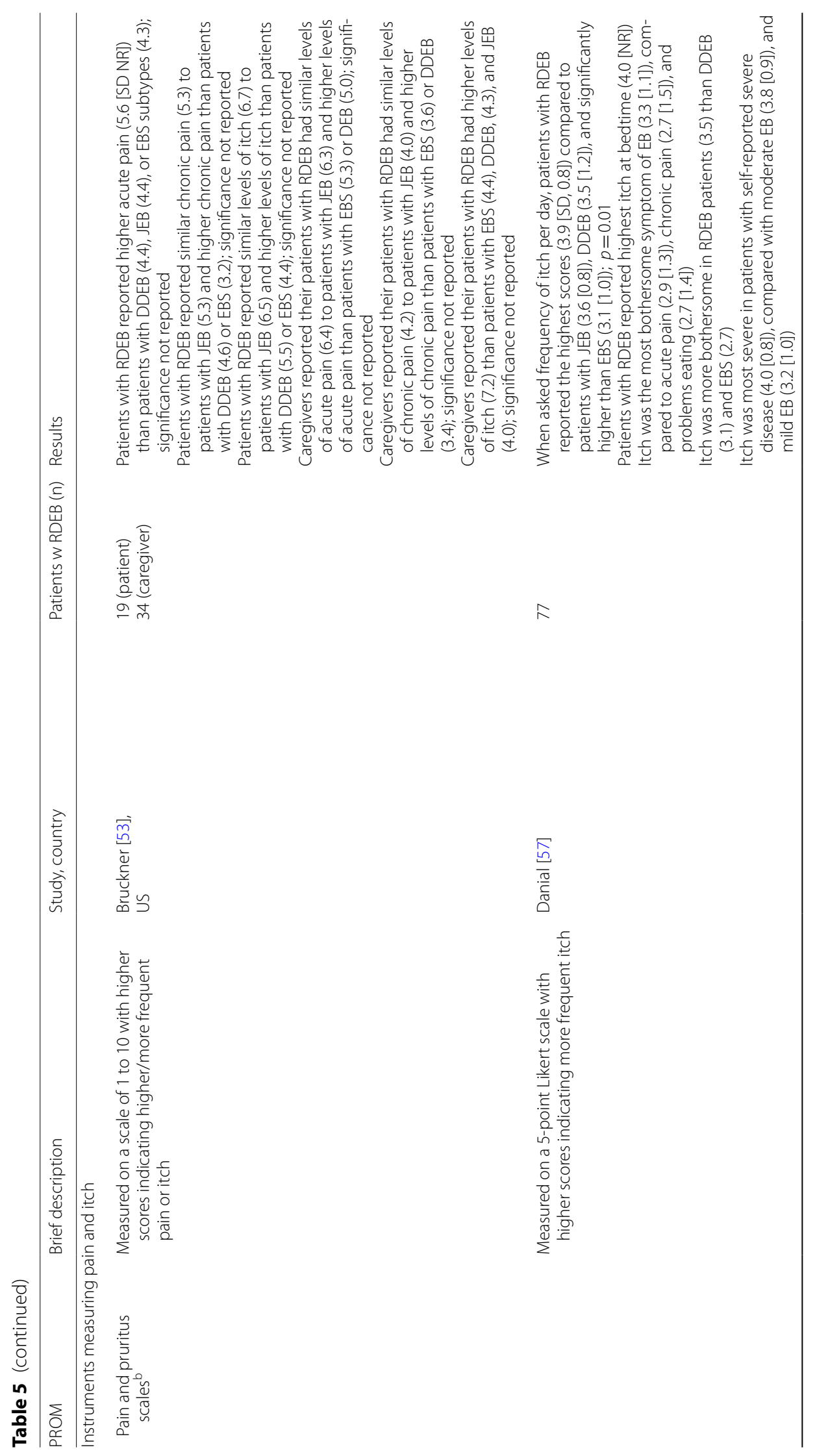




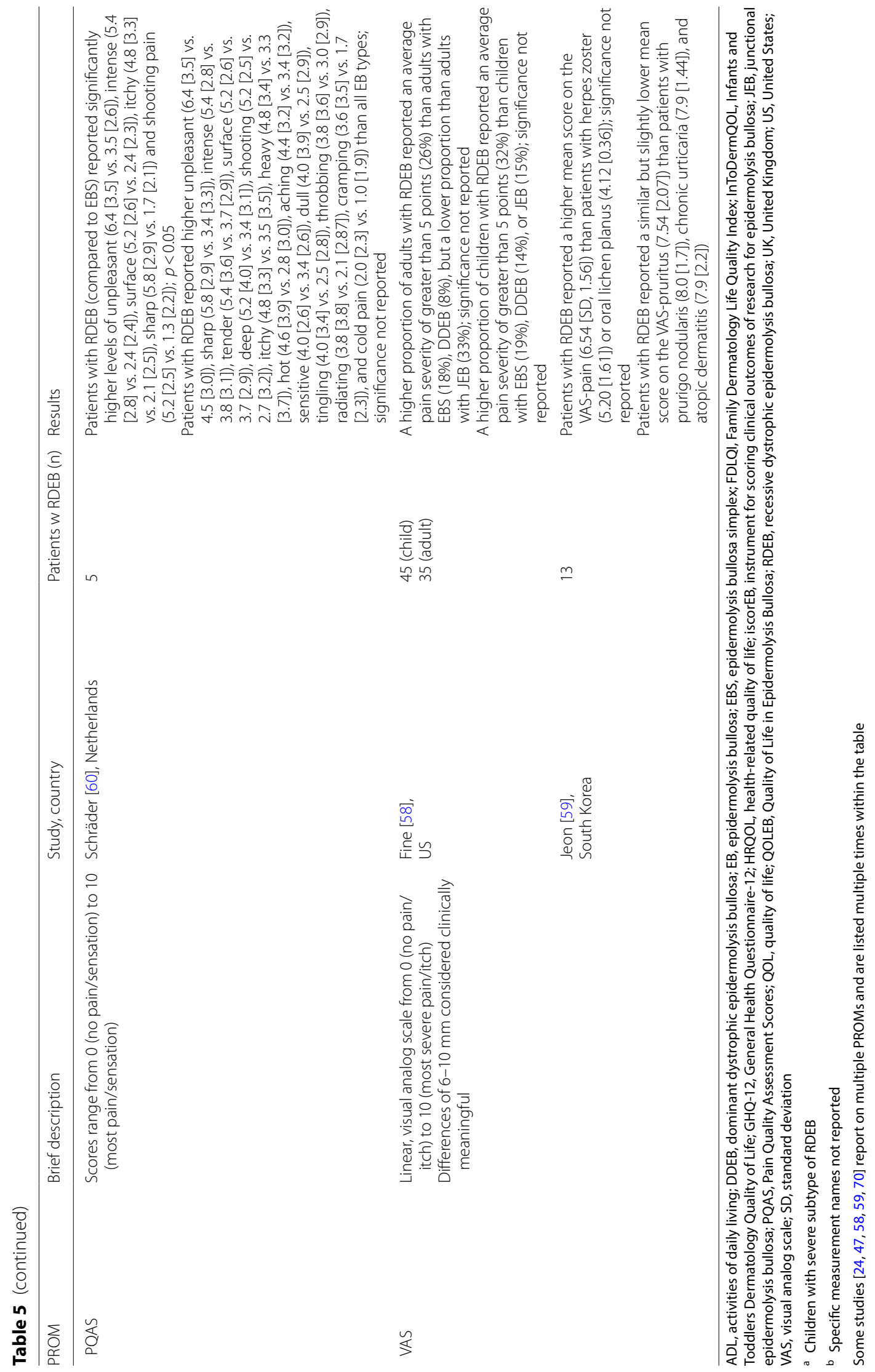



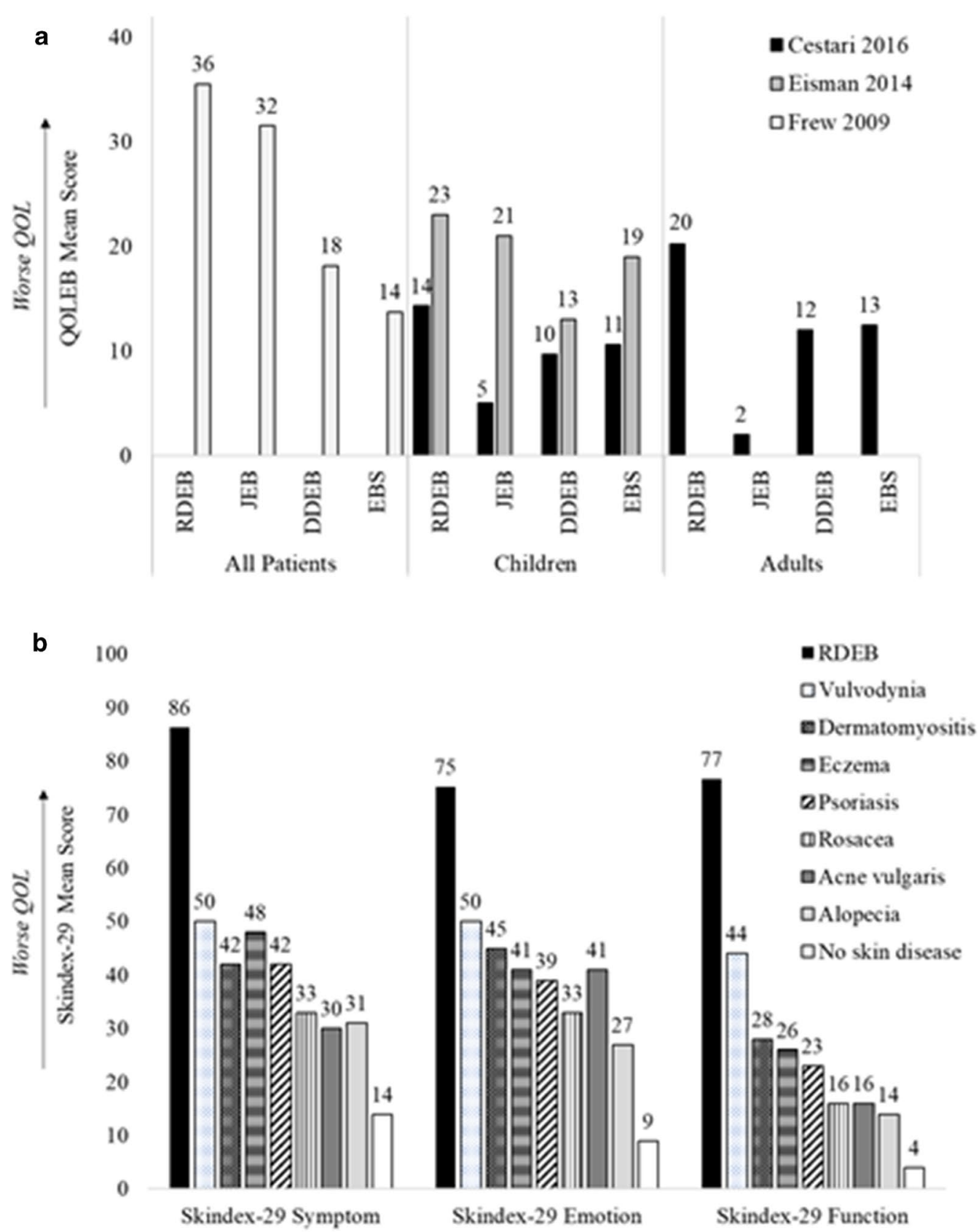

Fig. 2 Differences in QOL between a EB subtypes (via QOLEB'a), b skin diseases (via Skindex-29b). Adapted from: Cestari [69], Eisman [70], Frew [71], Jeon [59]. DDEB, dominant dystrophic epidermolysis bullosa; EB, epidermolysis bullosa; EBS, epidermolysis bullosa simplex; JEB, junctional epidermolysis bullosa; QOL, quality of life; QOLEB, Quality of Life in Epidermolysis Bullosa; RDEB, recessive dystrophic epidermolysis bullosa. aQOLEB is an EB-specific patient-reported outcome measure with scores ranging from 0 (best possible function/highest possible QOL) to 51 (lowest possible function/worst possible QOL). bSkindex-29 is a dermatology-specific patient-reported outcome measure with scores ranging from 0 (best possible QOL) to 100 (worst possible QOL)

energy to do more than care for their child. Of parents who divorced (22\%), 67\% reported that their child's disease was a major, if not primary, influencing factor in their divorce, and 30\% cited the financial burden of their child with RDEB as the reason for divorce. In an
Italian registry analysis of 62 patients with RDEB and their family caregivers (sample size not reported), the most frequently reported problems among caregivers were the time spent looking after their children with 
Table 6 Dressing- and medical-related expenses per patient per year

\begin{tabular}{|c|c|c|c|c|c|c|}
\hline Citation, study design & Country & Patient population & Sample size, N & $\begin{array}{l}\text { Cost per patient per } \\
\text { year }^{\mathrm{a}}\end{array}$ & Cost year & Definition \\
\hline \multicolumn{7}{|l|}{ Dressing costs } \\
\hline Jeon [59] & South Korea & RDEB & 13 & $\$ 4296$ & 2016 USD $^{c}$ & Dressings, fixing materi- \\
\hline Patient survey ${ }^{b}$ & & & & & & $\begin{array}{l}\text { als, topical agents and } \\
\text { medicines used during } \\
\text { changes }\end{array}$ \\
\hline Mellerio [62] & United Kingdom & RDEB & 40 & $\$ 9049$ & $2016 \mathrm{GBPC}$ & Cost of dressing \\
\hline \multirow{2}{*}{$\begin{array}{l}\text { Patient and caregiver } \\
\text { survey }^{\mathrm{b}}\end{array}$} & & RDEB, severe & 17 & $\$ 17,151$ & & Cost of dressings \\
\hline & & RDEB & 11 & $\$ 15,293$ & & $\begin{array}{l}\text { Cost of hours spent dress- } \\
\text { ing wounds }\end{array}$ \\
\hline $\begin{array}{l}\text { Grocott [76], single- } \\
\text { center, cross-sectional } \\
\text { survey }^{b}\end{array}$ & United Kingdom & $\begin{array}{l}\text { RDEB, with wounds } \\
\text { difficult to manage } \\
\text { with conventional } \\
\text { dressings }\end{array}$ & 11 & $\$ 28,727$ & 2012 GBP & $\begin{array}{l}\text { Dressing materials, costs } \\
\text { estimated via monthly } \\
\text { dressing orders }\end{array}$ \\
\hline Kirkorkian [77], & United States & RDEB, neonate & NA & $\$ 4,000-\$ 47,000$ & 2014 USD & $\begin{array}{l}\text { Cost of wound care } \\
\text { products obtained from } \\
\text { Amazon.com (August } \\
2012 \text { prices) based on } \\
\text { body-size }\end{array}$ \\
\hline \multirow[t]{2}{*}{ Cost exercise model } & & RDEB, infant & & $\$ 8,000-\$ 99,000$ & & \\
\hline & & RDEB, 10 year old & & $\$ 20,000-\$ 245,000$ & & \\
\hline $\begin{array}{l}\text { Flannery [78], Patient } \\
\text { survey }^{b}\end{array}$ & Ireland & EB & 5 (4 RDEB) & $\$ 32,256$ & 2020 EUR $^{C}$ & $\begin{array}{l}\text { Median wound and drugs } \\
\text { cost }\end{array}$ \\
\hline \multicolumn{7}{|c|}{ Medical, non-dressing-related costs } \\
\hline $\begin{array}{l}\text { Jeon [59], Patient } \\
\text { survey }^{b}\end{array}$ & South Korea & RDEB & 13 & $\$ 3096$ & 2016 USD & $\begin{array}{l}\text { All RDEB expenses exclud- } \\
\text { ing dressing costs }\end{array}$ \\
\hline $\begin{array}{l}\text { Mellerio [62], Patient } \\
\text { and caregiver survey }\end{array}$ & United Kingdom & RDEB & 10 & $\$ 1249^{d}$ & $2016 \mathrm{GBP}^{\mathrm{C}}$ & $\begin{array}{l}\text { Cost per hospital stay, } \\
\text { assuming } 212 \text { per day }\end{array}$ \\
\hline \multirow{4}{*}{$\begin{array}{l}\text { Flannery [78], Patient } \\
\text { survey }^{b}\end{array}$} & Ireland & EB & 5 (4 RDEB) & $\$ 84,534$ & 2020 EUR $^{C}$ & Median total medical costs \\
\hline & & & & $\$ 33,679$ & & $\begin{array}{l}\text { Median overnight hospital } \\
\text { costs, assuming } € 813 \\
\text { per night }\end{array}$ \\
\hline & & & & $\$ 2890$ & & $\begin{array}{l}\text { Median day clinic costs, } \\
\text { assuming } € 407 \text { per visit }\end{array}$ \\
\hline & & & & $\$ 1304$ & & $\begin{array}{l}\text { Median other primary care } \\
\text { costs, including GP visits, } \\
\text { physiotherapy, occupa- } \\
\text { tional therapy, public } \\
\text { health nurse visits }\end{array}$ \\
\hline
\end{tabular}

GBP, British pound sterling; GP, general practitioner; EB, epidermolysis bullosa; EUR, euro; NA, not applicable; NR, not reported; RDEB, recessive dystrophic epidermolysis bullosa; USD, United States dollar

a All costs converted to USD based on November 5, 2020 exchange rate

b Patient surveys were used to gather healthcare resource utilization and then local unit costs were applied to generate cost estimates

c Year of currency not defined, assumed to be publication year

d Cost reported per hospital stay not per year

RDEB, emotional distress, worsened physical wellbeing, and increased household expenditure [47].

\section{Economic burden}

Eight publications reported on economic outcomes in patients with RDEB or their families [53, 59, 61, 62, 7679]. Costs of wound care (including dressing and time costs), medical costs, and hospitalization costs were reported in South Korea [59], Ireland [78], the United Kingdom (UK) [62, 76], and the US [77]. 
Table 7 Time required for a dressing change and/or wound care in patients with RDEB

\begin{tabular}{|c|c|c|c|}
\hline & Bruckner [53] & Jeon [59] & Shayegan [79] \\
\hline $\mathrm{N}$, patients with RDEB & 53 & 13 & 90 \\
\hline Definition & $\begin{array}{l}\text { Whole body wound care including preparation } \\
\text { and cleanup }\end{array}$ & Dressing change & Dressing change \\
\hline \multicolumn{4}{|c|}{ Time required for dressing change, $n$ (\%) } \\
\hline$<2 \mathrm{~h}$ & $19(36)$ & $11(85)$ & NR \\
\hline $2-3 h$ & $21(40)$ & $2(15)$ & $27(30)^{\mathrm{a}}$ \\
\hline$>4 \mathrm{~h}$ & $13(25)$ & $0(0)$ & NR \\
\hline
\end{tabular}

$\mathrm{NR}$, not reported; RDEB, recessive dystrophic epidermolysis bullosa

a 2 hours was most commonly reported time taken to change dressings; no other time data on patients with RDEB were reported

\section{Direct costs and healthcare resource use}

Direct medical costs in patients with RDEB were high (Table 6) [59, 62, 76-78]. Medical expenses varied considerably; a patient survey in Ireland $(\mathrm{N}=5)$ reported median payer-borne total medical costs, consisting of costs for wound dressings, drugs, overnight hospital stays, and outpatient visits, to be $\$ 84,534$ per year [78], and a patient survey in South Korea $(\mathrm{N}=13)$ reported total patient-borne medical costs, comprising medical dressings and all other disease-related expenses, to be $\$ 7392$ per year [59]. Costs of wound dressing materials ranged from $\$ 4000-\$ 245,000$ in a US cost exercise model incorporating patient age and material quality [77], while costs of dressing materials reported in patient surveys from Ireland, South Korea, and the UK ranged from $\$ 4296-\$ 28,727$ [59, 62, 76]. Variations in cost are likely due to small sample sizes, contrasting health systems, and differences in EB subtypes. Patients with the severe subtype or complex wounds tended to report higher expenses [62, 76, 78].

Hospital resource use was reported in two studies in South Korea [59] and the UK [62], both with small samples. Almost half of patients in a South Korean survey were hospitalized in the previous year due to RDEB (6/13, 46\%) [59]. Five patients (39\%) were hospitalized for more than seven days. A survey of UK patients with RDEB $(\mathrm{N}=10)$ reported a median duration of hospital stay of four and a half days (range: 2-155 days) [62].

\section{Non-direct medical costs}

Frequency of dressing changes RDEB patients required frequent dressing changes [53, 59]. Seven of the $13(54 \%)$ patients included in the Korean survey reported daily dressing changes; two (31\%) reported dressing changes three times per week [59]. In a US survey of 53 RDEB patients and their caregivers, dressing change frequency depended on whether the wound was infected [53]. For non-infected wounds $42 \%$ (22/53) changed dressings daily and $34 \%(18 / 53)$ changed dressings every other day; for infected wounds, 47\% (25/53) changed dressings daily, $13 \%$ (7/53) changed dressings every other day, and $11 \%$ $(6 / 53)$ changed dressings two to three times per day.

Duration of dressing changes The time required for wound care was considerable (Table 7) [53, 59, 79]. A single-center survey of patients $(\mathrm{N}=11)$ in the $\mathrm{UK}$ reported a median time of $25.25 \mathrm{~h}$ per week (101 h per month) spent on wound dressings [76]. In a US and Canadian survey, the majority of patients $(55 / 90,61 \%)$ required the assistance of one person for dressing changes; $17 \%$ (15/90) required two assistants [79]. Only $22 \%$ (20/90) did not require assistance.

\section{Overall financial burden}

The overall financial burden of RDEB was reported in two studies [59, 61]. In the Korean survey, over half of respondents $(7 / 13,54 \%)$ reported always experiencing economic burden due to dressing materials [59]. Similarly, in a US survey, half $(16 / 32,50 \%)$ of respondents reported a high or severe level of impact on finances due to their disease [61].

Data on the indirect costs of RDEB, including impact on employment and productivity loss in patients with RDEB and their families, were not identified.

\section{Discussion}

This study is, to our knowledge, the first published systematic literature review (SLR) to comprehensively describe the clinical, humanistic, and economic burden of disease in patients with RDEB. A total of 65 studies met inclusion criteria for this systematic literature review, and, together, the data indicated that the cost of disease care, including wound management, in patients with RDEB and their families is considerable. Significant time was spent dressing wounds and the patient-borne 
expenses associated with wound dressing materials were high.

Patients with RDEB experienced a significant impact on QOL due to their disease compared to other EB subtypes, skin diseases, and healthy controls and experience severe limitations in function and social activities. Furthermore, the humanistic and economic burden of RDEB extended beyond the patient to affect families and their interpersonal relationships.

A considerable burden was associated with large wounds, associated pain and itch, and multiple other comorbidities including infection, anemia, strictures and stenoses, contractures, difficulty walking, and failure to thrive. Patients with RDEB also had an increased risk of premature mortality due to pneumonia, sepsis, organ failure, and failure to thrive. Many patients developed SCC and associated complications in adulthood which can frequently be lethal. Finally, patients with RDEB underwent serious and intensive surgeries to manage their disease including esophageal dilation, gastrostomy tube placement, pseudosyndactyly release, and amputation. Our review also found that approximately 1 out of every 4 patients with RDEB do not undergo any confirmatory diagnostic testing and 1 out of every 3 do not undergo genetic analysis, though both are recommended by clinical practice guidelines $[23,80]$. This is in contrast to the US and many western European countries, where the vast majority of RDEB patients are genotyped. Identification of the causative mutation via genetic testing provides patients with a definitive diagnosis, estimation of disease prognosis, and potential inclusion into clinical trials [81].

One systematic review of the natural history of RDEB reported preliminary results as the first stage of development of a longitudinal cohort study in the UK (PEBLES) [82]. The authors identified limitations such as small sample sizes, high numbers of single-center studies, limited longitudinal data, unclear or no identified RDEB subtypes, and mixing of results between RDEB and other EB subtypes. Furthermore, they identified limited-to-no data on subjective or psychosocial aspects of RDEB and the economic burden of the disease. An SLR conducted by Montaudié and colleagues on SCC and EB reported the highest incidence of SCC in EB to occur in patients with RDEB, development of SCC to arise primarily in upper and lower extremities, and in areas with chronic wounds [83]. Findings from both of these reviews are consistent with our own.

\section{Limitations of the existing literature}

Several limitations within the existing body of literature were identified. First, sample sizes of studies were generally small and many studies were single-center, making generalizations from the study population to the larger RDEB population difficult or impossible. Additionally, almost all studies were cross-sectional, without longitudinal assessment of clinical, economic, or humanistic burden over the patient's lifetime. The severe and lifelong nature of RDEB would best be assessed by following patients over months or years to evaluate changes over time.

Second, as there are likely RDEB patients with milder phenotypes who have been misdiagnosed [3] or were underreported, these milder RDEB presentations are likely underrepresented in the literature. Thus, it is likely that severe and systemic manifestations such as non-esophageal strictures and stenoses, pseudosyndactyly, and microstomia, are overreported. Furthermore, in some studies, there is no distinction made between RDEB subtype or severity of disease. Additionally, some studies also included other types of EB such as DDEB or EBS, making generalizations about RDEB more difficult.

Third, economic data was limited and cost comparisons across studies and populations were difficult due to differences in currencies, health systems, and cost definitions. Furthermore, indirect costs such as impact on employment and productivity loss were not available. Additionally, evidence on satisfaction and/or burden associated with treatment was minimal.

Finally, disease burden in the literature may have been applicable to RDEB patients but reported in a larger EB cohort, and thus, not met inclusion criteria into the review. For instance, Danial and colleagues highlighted itch as the most bothersome symptom among all EB patients, including those with RDEB, but these data were not included in our results as they were not specific to RDEB patients [57].

Despite these limitations, the available literature suggests that the clinical, humanistic, and economic burden of RDEB is substantial.

\section{Future research directions}

Further research on the long-term impact of RDEB is needed to better understand how the burden of disease changes over the patient lifetime and stratified by disease severity. Recent research has shown a moderate-to-major financial impact of disease on patients with RDEB and high out-of-pocket dressing costs [84], but quantification of the economic burden across populations, geographies and healthcare systems is needed to provide appropriate care for patients. Further evaluation of the presence of anxiety, depression, and other mental health disorders that impact the humanistic burden of RDEB is also needed. Additionally, future research should measure the change in burden of disease as disease modifying 
treatments for RDEB, such as gene therapies, enter the market and are utilized.

\section{Conclusion}

Collectively, the evidence identified in this review suggests a critical unmet need for RDEB treatment options that addresses the underlying disorder. RDEB is associated with significant humanistic and economic burden on patients and their families/caregivers in addition to the clinical burden. New therapies that target the underlying disorder and stand to reduce wound burden could help address the overall disease burden.

\begin{abstract}
Abbreviations
BMI: Body Mass Index; C7: Type VII collagen; DDEB: Dominant dystrophic epidermolysis bullosa; DEB: Dystrophic epidermolysis bullosa; DEBRA: Dystrophic Epidermolysis Bullosa Research Association; EB: Epidermolysis bullosa; EBS: Epidermolysis bullosa simplex; iscorEB: Instrument for scoring clinical outcomes of research for epidermolysis bullosa; PROM: Patient-reported outcome measure; QOL: Quality of life; QOLEB: Quality of Life in Epidermolysis Bullosa; RDEB: Recessive dystrophic epidermolysis bullosa; SCC: Squamous cell carcinoma; SLR: Systematic literature review; UK: United Kingdom; US: United States; VAS: Visual Analogue Scale.
\end{abstract}

\section{Supplementary Information}

The online version contains supplementary material available at https://doi. org/10.1186/s13023-021-01811-7.

Additional file 1: Included studies.

\section{Acknowledgements}

Sophie Tsai assisted in literature screening and data extraction.

\section{Authors' contributions}

Conception and design, EL, DP, JG, and DR; acquisition and interpretation of data, EL, DP; screening and extraction, EL, DP; manuscript, JYT, MPM, EL, EG, $A C, Y L, J G, D P$, and DR. All authors read and approved the final manuscript.

\section{Funding}

JT receives research funding from Abeona Therapeutics, Phoenix Tissue Repair, and EB Research Partnership. YL receives research funding from Castle Creek Pharmaceuticals, Phoenix Tissue Repair, Merck and Abeona Therapeutics. EG receives research funding from Abeona Therapeutics, Phoenix Tissue Repair, and EB Research Partnership. MPM receives research funding from Abeona Therapeutics, Castle Creek Pharmaceuticals, WINGS Pharmaceuticals, Krystal Biotech, and Phoenix Tissue Repair. AC receives research funding from Abeona Therapeutics, Phoenix Tissue Repair, and EB Research Partnership. DR and JG are employees of Abeona Therapeutics. EL and DP are employees of Pharmerit-An Open Health Company and were paid consultants to Abeona Therapeutics in connection with this research.

\section{Availability of data and materials}

Data sharing is not applicable to this article as no datasets were generated or analyzed during the current study.

\section{Declarations}

Ethics approval and consent to participate

Not applicable.

\section{Consent for publication}

Not applicable.

\section{Competing interests}

JYT and MPM are investigators for Abeona Therapeutics (VIITAL trial). YL serves in consulting/advisory roles to Nektar Therapeutics and Gilead Sciences. JYT serves in a consulting role to BridgeBio Pharma and PellePharm. AC serves in a consulting/advisory role to Pfizer and AbbVie.

\section{Author details}

${ }^{1}$ Department of Dermatology, Stanford Universixsty School of Medicine, 291 Campus Drive, Stanford, CA 94305, USA. ${ }^{2}$ Pharmerit - An OPEN Health Company, 4350 East West Highway, Suite 1100, Bethesda, MD 20814, USA. ${ }^{3}$ Abeona Therapeutics Inc, 1330 Avenue of the Americas, New York, NY 10019 , USA.

Received: 3 December 2020 Accepted: 31 March 2021

Published online: 13 April 2021

\section{References}

1. Soro L, Bartus C, Purcell S. Recessive dystrophic epidermolysis bullosa: a review of disease pathogenesis and update on future therapies. J Clin Aesthet Dermatol. 2015;8(5):41-6.

2. Fine J-D. Epidemiology of inherited epidermolysis bullosa based on incidence and prevalence estimates from the National Epidermolysis Bullosa Registry. JAMA Dermatol. 2016;152(11):1231-8.

3. Eichstadt S, Tang JY, Solis DC, Siprashvili Z, Marinkovich MP, Whitehead $\mathrm{N}$, et al. From clinical phenotype to genotypic modelling: incidence and prevalence of recessive dystrophic epidermolysis bullosa (RDEB). Clin Cosmet Investig Dermatol. 2019;12:933-42.

4. Fine J-D, Bruckner-Tuderman L, Eady RAJ, Bauer EA, Bauer JW, Has C, et al. Inherited epidermolysis bullosa: updated recommendations on diagnosis and classification. J Am Acad Dermatol. 2014;70(6):1103-26.

5. Has C, Bauer JW, Bodemer C, Bolling MC, Bruckner-Tuderman L, Diem A, et al. Consensus reclassification of inherited epidermolysis bullosa and other disorders with skin fragility. Br J Dermatol. 2020;183(4):614-27.

6. Kim M, Li M, Intong-Wheeler LRA, Tran K, Marucci D, Murrell DF. Epidemiology and outcome of squamous cell carcinoma in epidermolysis bullosa in Australia and New Zealand. Acta Derm Venereol. 2018;98(1):70-6.

7. Rashidghamat E, McGrath JA. Novel and emerging therapies in the treatment of recessive dystrophic epidermolysis bullosa. Intract Rare Dis Res. 2017;6(1):6-20.

8. Denyer J, Pillay E, Clapman J. Best practice guidelines for skin and wound care in epidermolysis bullosa. London, UK: Dystrophic Epidermolysis Bullosa Research Association; 2017 [cited 2021 January 15]. https://www. woundsinternational.com/resources/details/best-practice-guidelinesskin-and-wound-care-in-epidermolysis-bullosa.

9. Liy-Wong C, Ali A, Aujla N, Briggs L, Campbell F, El Hamouly A, et al. Epidermolysis bullosa, a handbook for EB patients and families. Toronto, ON: DEBRA Canada; [cited 2021 January 15]. https://www.sickkids.ca/Derma tology/What-we-do/76382-EBook_Final_Interactive.pdf.

10. Center for Drug Evaluation and Research, Center for Biologics Evaluation and Research. Epidermolysis bullosa: developing drugs for treatment of cutaneous manifestations, guidance for industry. Silver Spring, MD: Food and Drug Administration; 2019 [cited 2021 January 15]. https://www. fda.gov/regulatory-information/search-fda-guidance-documents/epide rmolysis-bullosa-developing-drugs-treatment-cutaneous-manifestationsguidance-industry.

11. Dourado Alcorte M, Sogayar MC, Demasi MA. Patent landscape of molecular and cellular targeted therapies for recessive dystrophic epidermolysis bullosa. Expert Opin Ther Pat. 2019;29(5):327-37.

12. Eichstadt S, Barriga M, Ponakala A, Teng C, Nguyen NT, Siprashvili Z, et al. Phase 1/2a clinical trial of gene-corrected autologous cell therapy for recessive dystrophic epidermolysis bullosa. JCI Insight. 2019;4(19):e130554.

13. Marinkovich MP, Tang JY. Gene therapy for epidermolysis bullosa. J Investig Dermatol. 2019;139(6):1221-6.

14. Siprashvili Z, Nguyen NT, Gorell ES, Loutit K, Khuu P, Furukawa LK, et al. Safety and wound outcomes following genetically corrected autologous epidermal grafts in patients with recessive dystrophic epidermolysis bullosa. JAMA. 2016;316(17):1808-17. 
15. Moher D, Liberati A, Tetzlaff J, Altman DG. Preferred reporting items for systematic reviews and meta-analyses: the PRISMA statement. PLoS Med. 2009;6(7):e1000097.

16. Abahussein AA, Al-Zayir AA, Mostafa WZ, Okoro AN. Epidermolysis bullosa in the Eastern Province of Saudi Arabia. Int J Dermatol. 1993;32(8):579-81.

17. Alband N, Kumar DS, Jones R, James D, Ogboli M, Browne F, et al. Morbidity and mortality in U.K. children with recessive dystrophic epidermolysis bullosa: 16-year data from the National UK. EB Registry. British Journal of Dermatology. 2016;175:161.

18. Castro LC, Nobrega Y, Gandolfi L, Pratesi R. Bone mass and Vitamin D status in children and adolescents with generalized epidermolysis bullosa. Hormone Res Paediat. 2016:86:179.

19. Chernyshov PV, Suru A, Gedeon I, Derevyanko LA, Tiplica GS, Salavastru CM. Epidermolysis bullosa-specific module of the Infants and Toddlers Dermatology Quality of Life (InToDermQoL) questionnaire. J Eur Acad Dermatol Venereol. 2019;33(3):612-7.

20. Colomb V, Bourdon-Lannoy E, Lambe C, Sauvat F, Hadj Rabia S, Teillac D, et al. Nutritional outcome in children with severe generalized recessive dystrophic epidermolysis bullosa: a short- and long-term evaluation of gastrostomy and enteral feeding. Br J Dermatol. 2012;166(2):354-61.

21. Čolović A, Jovičić O, Stevanović R, Ivanović M. Oral health status in children with inherited dystrophic epidermolysis bullosa. Vojnosanit Pregl. 2017;74(7):644-51.

22. Fantauzzi RS, Maia MO, Cunha FC, Simões RV, Gonçalves DU, Maia AF. Otorhinolaryngological and esophageal manifestations of epidermolysis bullosa. Braz J Otorhinolaryngol. 2008;74(5):657-61.

23. Feinstein JA, Jambal P, Peoples K, Lucky AW, Khuu P, Tang JY, et al. Assessment of the timing of milestone clinical events in patients with epidermolysis bullosa from North America. JAMA Dermatol. 2018;155(2):196-203.

24. Feldmann R, Weglage J, Frosch M. Cognitive function in patients with epidermolysis bullosa: social adjustment and emotional problems. Klin Padiatr. 2012;224(1):22-5.

25. Fine JD, Hall M, Weiner M, Li KP, Suchindran C. The risk of cardiomyopathy in inherited epidermolysis bullosa. Br J Dermatol. 2008;159(3):677-82.

26. Fine J-D, Johnson LB, Weiner M, Li K-P, Suchindran C. Epidermolysis bullosa and the risk of life-threatening cancers: the National EB Registry experience, 1986-2006. J Am Acad Dermatol. 2009;60(2):203-11.

27. Fine J-D, Johnson LB, Weiner M, Stein A, Cash S, DeLeoz J, et al. Genitourinary complications of inherited epidermolysis bullosa: experience of the national epidermylosis bullosa registry and review of the literature. J Urol. 2004;172(5 I):2040-4.

28. Fine J-D, Johnson LB, Weiner M, Stein A, Cash S, DeLeoz J, et al. Pseudosyndactyly and musculoskeletal contractures in inherited epidermolysis bullosa: experience of the national epidermolysis bullosa registry, 1986-2002. J Hand Surg. 2005;30(1):14-22.

29. Fine J-D, Johnson LB, Weiner M, Suchindran C. Tracheolaryngeal complications of inherited epidermolysis bullosa: cumulative experience of the national epidermolysis bullosa registry. Laryngoscope. 2007;117(9):1652-60.

30. Fine J-D, Johnson LB, Weiner M, Suchindran C. Gastrointestinal complications of inherited epidermolysis bullosa: cumulative experience of the national epidermolysis bullosa registry. J Pediatr Gastroenterol Nutr. 2008;46(2):147-58.

31. Freeman EB, Köglmeier J, Martinez AE, Mellerio JE, Haynes L, Sebire NJ, et al. Gastrointestinal complications of epidermolysis bullosa in children. Br J Dermatol. 2008;158(6):1308-14

32. Guerra-Leal JD, Meester I, Cantu-Gonzalez JR, Ornelas-Cortinas G, Montemayor-Martinez A, Salas-Alanis JC. The importance of esophagography in patients with recessive dystrophic epidermolysis bullosa. Am J Roentgenol. 2016;207(4):778-81.

33. Horn HM, Tidman MJ. The clinical spectrum of dystrophic epidermolysis bullosa. Br J Dermatol. 2002;146(2):267-74.

34. Hwang SJE, Daniel BS, Fergie B, Davey J, Murrell DF. Prevalence of anemia in patients with epidermolysis bullosa registered in Australia. Int J Women's Dermatol. 2015;1(1):37-40.

35. Intong LRA, Choi SD, Shipman A, Kho YC, Hwang SJE, Rhodes LM, et al. Retrospective evidence on outcomes and experiences of pregnancy and childbirth in epidermolysis bullosa in Australia and New Zealand. Int J Women's Dermatol. 2017;3(1):S1-5.
36. Jefferies JL, Towbin J, Ryan T, Lucky A. Cardiovascular findings in recessive dystrophic epidermolysis bullosa. J Am Coll Cardiol. 2013;61(10):E589.

37. Jones SM, Smith KA, Jain M, Mellerio JE, Martinez A, Nischal KK. The frequency of signs of meibomian gland dysfunction in children with epidermolysis bullosa. Ophthalmology. 2016;123(5):991-9.

38. Kaneko K, Kakuta M, Ohtomo Y, Shimizu T, Yamashiro Y, Ogawa H, et al. Renal amyloidosis in recessive dystrophic epidermolysis bullosa. Dermatology. 2000;200(3):209-12.

39. Lara-Corrales I, Mellerio JE, Martinez AE, Green A, Lucky AW, Azizkhan $R G$, et al. Dilated cardiomyopathy in epidermolysis bullosa: a retrospective, multicenter study. Pediatr Dermatol. 2010;27(3):238-43.

40. Markos P, Karaman M, Murat-Susic S, Omerza L, Pulanic R, Rustemovic N. Dilatation of esophageal strictures in epidermolysis bullosa patients: a single center experience. Esophagus. 2016;13:378-82.

41. McDonald C, Roebuck D, Mellerio J, Martinez A. Can we predict the chronology of oesophageal strictures in paediatric epidermolysis bullosa patients? A prospective study of 75 children. Br J Dermatol. 2018;179:165-6.

42. Mellado F, Fuentes I, Palisson F, I Vergara J, Kantor A. Ophthalmologic approach in epidermolysis bullosa: a cross-sectional study with phenotype-genotype correlations. Cornea. 2018;37(4):442-7.

43. Nomura K, Imaizumi T, Sato T, Hashimoto I. Clinical criteria for differentiating between recessive and dominant forms of dystrophic epidermolysis bullosa, elaborated from an analysis of 119 cases. J Dermatol. 1993:20(5):269-75.

44. Rao A, Mellerio JE, Sklar M, Brain C, Allgrove J, Sanderson IR, et al. Growth impaired children with epidermolysis bullosa have increased serum markers of inflammation and reduced circulating IGF-I/IGFBP-3. Pediatr Res. 2011;70:294.

45. Ryan TD, Lucky AW, King EC, Huang G, Towbin JA, Jefferies JL. Ventricular dysfunction and aortic dilation in patients with recessive dystrophic epidermolysis bullosa. Br J Dermatol. 2016;174(3):671-3.

46. Ryan TD, Lucky AW, Towbin J, Jefferies J. Ventricular dysfunction and aortic dilation in patients with recessive dystrophic epidermolysis bullosa. J Am Coll Cardiol. 2015;65(10):A944.

47. Sampogna F, Tabolli S, Di Pietro C, Castiglia D, Zambruno G, Abeni D. The evaluation of family impact of recessive dystrophic epidermolysis bullosa using the Italian version of the family dermatology life quality index. J Eur Acad Dermatol Venereol. 2013;27(9):1151-5.

48. Serrano-Martínez MC, Bagán JV, Silvestre FJ, Viguer MT. Oral lesions in recessive dystrophic epidermolysis bullosa. Oral Dis. 2003;9(5):264-8.

49. Sidwell RU, Yates $R$, Atherton D. Dilated cardiomyopathy in dystrophic epidermolysis bullosa. Arch Dis Child. 2000;83(1):59-63.

50. Stellingsma C, Dijkstra PU, Dijkstra J, Duipmans JC, Jonkman MF, Dekker R. Restrictions in oral functions caused by oral manifestations of epidermolysis bullosa. Eur J Dermatol. 2011;21(3):405-9.

51. Tong L, Hodgkins PR, Denyer J, Brosnahan D, Harper J, RussellEggitt I, et al. The eye in epidermolysis bullosa. Br J Ophthalmol. 1999;83(3):323-6.

52. Wagner JE, Ishida-Yamamoto A, McGrath JA, Hordinsky M, Keene DR, Riddle MJ, et al. Bone marrow transplantation for recessive dystrophic epidermolysis bullosa. N Engl J Med. 2010;363(7):629-39.

53. Bruckner AL, Losow M, Wisk J, Patel N, Reha A, Lagast H, et al. The challenges of living with and managing epidermolysis bullosa: insights from patients and caregivers. Orphanet J Rare Dis. 2020;15(1):1.

54. Eng VA, Solis DC, Gorell ES, Choi S, Nazaroff J, Li S, et al. Patient reported outcomes and quality of life in recessive dystrophic epidermolysis bullosa: a global cross-sectional survey. J Am Acad Dermatol. 2020. https://doi.org/10.1016/j.jaad.2020.03.028. Online ahead of print.

55. Reimer A, Hess M, Schwieger-Briel A, Kiritsi D, Schauer F, Schumann $\mathrm{H}$, et al. Natural history of growth and anaemia in children with epidermolysis bullosa: a retrospective cohort study. Br J Dermatol. 2019;182:1437-48.

56. Teng C, Solis D, Tang J, Barriga M, Marinkovich MP. 251 Natural history of wounds in patients with recessive dystrophic epidermolysis bullosa. J Investig Dermatol. 2019;139(5):S43.

57. Danial C, Adeduntan R, Gorell ES, Lucky AW, Paller AS, Bruckner A, et al. Prevalence and characterization of pruritus in epidermolysis bullosa. Pediatr Dermatol. 2015;32(1):53-9. 
58. Fine JD, Johnson LB, Weiner M, Suchindran C. Assessment of mobility, activities and pain in different subtypes of epidermolysis bullosa. Clin Exp Dermatol. 2004;29(2):122-7.

59. Jeon IK, On HR, Kim S-C. Quality of life and economic burden in recessive dystrophic epidermolysis bullosa. Ann Dermatol. 2016;28(1):6-14.

60. Schräder NHB, Yuen WY, Jonkman MF. Pain quality assessment scale for epidermolysis bullosa. Acta Derm Venereol. 2018;98(3):346-9.

61. Choi S, Solis D, Nazaroff J, Bailey-Healy I, Barriga M, Dutt-Singkh Y, et al. Quality of life in recessive dystrophic epidermolysis bullosa: the AltaVoice patient registry, 2012-2015. J Investig Dermatol. 2017;137(5):S38.

62. Mellerio J. PEBLES: natural history of RDEB. DEBRA International Congress; Zagreb, Croatia2016. p. 1-48.

63. Fine J-D, Johnson LB, Weiner M, Suchindran C. Cause-specific risks of childhood death in inherited epidermolysis bullosa. J Pediatr. 2008;152(2):276-80.e2.

64. Castelo B, Viñal D, Maseda R, Ostios L, Sánchez D, García-Salvatierra B, et al. Epidemiology and natural history of cutaneous squamous cell carcinoma in recessive dystrophic epidermolysis bullosa patients: 20 years' experience of a reference centre in Spain. Clin Transl Oncol. 2019;21:1573-7.

65. Haynes L, Mellerio JE, Martinez AE. Gastrostomy tube feeding in children with epidermolysis bullosa: Consideration of key issues. Pediatr Dermatol. 2012;29(3):277-84.

66. Lin Y-C, Golianu B. Anesthesia and pain management for pediatric patients with dystrophic epidermolysis bullosa. J Clin Anesth. 2006;18(4):268-71.

67. Andreoli E, Mozzetta A, Angelo C, Paradisi M, Foglio Bonda PG. Epidermolysis bullosa. Psychological and psychosocial aspects. Dermatol Psychosomat. 2002;3(2):77-81.

68. Bruckner AL, Fairclough DL, Feinstein JA, Lara-Corrales I, Lucky AW, Tolar J, et al. Reliability and validity of the instrument for scoring clinical outcomes of research for epidermolysis bullosa (iscorEB). Br J Dermatol. 2018;178(5):1128-34

69. Cestari T, Prati C, Menegon DB, Prado Oliveira ZN, Machado MCR, Dumet $J$, et al. Translation, cross-cultural adaptation and validation of the quality of life evaluation in Epidermolysis Bullosa instrument in Brazilian Portuguese. Int J Dermatol. 2016;55(2):e94-9.

70. Eismann EA, Lucky AW, Cornwall R. Hand function and quality of life in children with epidermolysis bullosa. Pediatr Dermatol. 2014;31(2):176-82.

71. Frew JW, Martin LK, Nijsten T, Murrell DF. Quality of life evaluation in epidermolysis bullosa (EB) through the development of the QOLEB questionnaire: an EB-specific quality of life instrument. Br J Dermatol. 2009;161(6):1323-30.

72. Schwieger-Briel A, Chakkittakandiyil A, Lara-Corrales I, Aujla N, Lane AT, Lucky AW, et al. Instrument for scoring clinical outcome of research for epidermolysis bullosa: a consensus-generated clinical research tool. Pediatr Dermatol. 2015;32(1):41-52.

73. Soon K, Mason R, Martinez AE, Mellerio JE. The psychological functioning of children with epidermolysis bullosa and its relationship with specific aspects of disease. Br J Dermatol. 2020;182(3):789-90.

74. Moss C, Wong A, Davies P. The Birmingham Epidermolysis Bullosa Severity score: development and validation. Br J Dermatol. 2009;160(5):1057-65.

75. Fine J-D, Johnson LB, Weiner M, Suchindran C. Impact of inherited epidermolysis bullosa on parental interpersonal relationships, marital status and family size. Br J Dermatol. 2005;152(5):1009-14.

76. Grocott P, Graham T, Blackwell R, Currie C, Pillay E, Clapham J, et al. Individualising wound care research: the woundcare for epidermolysis bullosa project. Wounds UK. 2013;9(3):23-32.

77. Kirkorian AY, Weitz NA, Tlougan B, Morel KD. Evaluation of wound care options in patients with recessive dystrophic epidermolysis bullosa: a costly necessity. Pediatr Dermatol. 2014;31(1):33-7.

78. Flannery D, Doyle C, Hickey S, Aherne F, Kenan A. Direct costs of epidermolysis bullosa by disease severity. Acta Dermatovenereol. 2020;100(8):adv00116.

79. Shayegan LH, Levin LE, Galligan ER, Lucky AW, Bruckner AL, Pope E, et al. Skin cleansing and topical product use in patients with epidermolysis bullosa: results from a multicenter database. Pediatr Dermatol. 2020;37(2):326-32.

80. Has C, Liu L, Bolling MC, Charlesworth AV, El Hachem M, Escámez MJ, et al. Clinical practice guidelines for laboratory diagnosis of epidermolysis bullosa. Br J Dermatol. 2020;182(3):574-92.

81. Sánchez-Jimeno C, Escámez MJ, Ayuso C, Trujillo-Tiebas MJ, Del Río M. Genetic diagnosis of epidermolysis bullosa: recommendations from an expert Spanish research group. Actas Dermosifiliogr. 2018;109(2):104-22.

82. Mellerio J, Robertson S, Pillay E, Denyer J, Wedgeworth E, Batten E, et al. A systematic review of the natural history of recessive dystrophic epidermolysis bullosa. Br J Dermatol. 2015;173:42.

83. Montaudié $H$, Chiaverini C, Sbidian E, Charlesworth A, Lacour JP. Inherited epidermolysis bullosa and squamous cell carcinoma: a systematic review of 117 cases. Orphanet J Rare Dis. 2016;11:117.

84. Gorell ES, Wolstencroft PW, de Souza MP, Murrell DF, Linos E, Tang JY. Financial burden of epidermolysis bullosa on patients in the United States. Pediatr Dermatol. 2020;37(6):1198-201.

\section{Publisher's Note}

Springer Nature remains neutral with regard to jurisdictional claims in published maps and institutional affiliations.
Ready to submit your research? Choose BMC and benefit from:

- fast, convenient online submission

- thorough peer review by experienced researchers in your field

- rapid publication on acceptance

- support for research data, including large and complex data types

- gold Open Access which fosters wider collaboration and increased citations

- maximum visibility for your research: over $100 \mathrm{M}$ website views per year

At BMC, research is always in progress.

Learn more biomedcentral.com/submissions 